\title{
Changes in household food security, access to health services, and income in northern Lao PDR during the COVID- 19 pandemic
}

Jennifer R. Head, MPH ${ }^{* 1}$, Phetsavanh Chanthavilay, MD, $\mathrm{PhD}^{2}$, Helen Catton ${ }^{3}$, Ammaline Vongsitthi, $\mathrm{MD}^{3}$, Kelley Khamphouxay ${ }^{3}$, Niphone Simphaly, MD

1. Department of Epidemiology, University of California Berkeley, Berkeley, USA

2. University of Health Sciences, Vientiane, Lao PDR

3. Save the Children International, Lao PDR

4. Provincial Health Department, Luang Prabang, Lao PDR

* Corresponding author:

Jennifer R. Head, MPH

Email: jennifer_head@berkeley.edu

Keywords: food security; dietary diversity; underweight; wasting; income; COVID-19; Lao PDR; malnutrition; local food production

\begin{abstract}
Background: The COVID-19 pandemic is expected to exacerbate food insecurity in low- and middle-income countries, through loss of income and disrupted food supply chains. Lao PDR has among the highest rates of malnutrition in Southeast Asia. We assessed the relative difficulty in meeting food needs during the COVID-19 pandemic in rural districts of Luang Prabang Province, Lao PDR compared to before; determined associations between pandemic-associated difficulties in food access and household, maternal and child food security; and identified resiliency-promoting strategies.
\end{abstract}

Methods: In November 2020, households $(N=1,122)$ with children under five years were interviewed. Respondents reported the relative ease of access of food and health care as well as changes in income and expenditures compared to before March 2020. We used generalized linear models with cluster robust standard errors to assess univariate and multivariate associations.

Results: Nearly four-fifths (78.5\%) found it harder to meet household food needs during the pandemic. The most common reasons were increased food prices $(51.2 \%)$, loss of 
medRxiv preprint doi: https://doi.org/10.1101/2021.07.27.21261221; this version posted July 30, 2021. The copyright holder for this preprint (which was not certified by peer review) is the author/funder, who has granted medRxiv a license to display the preprint in perpetuity. It is made available under a CC-BY-ND 4.0 International license .

income (45.3\%), and decreased food availability (36.6\%). Adjusting for demographics, households with increased difficulty meeting food needs had lower food consumption scores and child dietary diversity. Over $85 \%$ of households lost income during the pandemic. Decreased expenditures was associated with reliance on more extreme coping strategies to meet food needs. The households who experienced no change in meeting food needs produced a greater percentage of their food from homegrown methods (4.22\% more, $95 \% \mathrm{Cl}: 1.28,7.15)$, than households who found it more difficult. We estimated that decreases in child bodyweight by $0.5-1 \%$ would increase wasting in this population by $1.7-2.1$ percentage points.

Conclusions: Pandemic-associated shocks may have large effects on malnutrition prevalence. Action is needed to mitigate consequences of the pandemic on nutrition. Local food production and safety net programs that offset income losses may help.

\section{List of abbreviations:}

LMICs: low- and middle-income countries

FAO: Food and agriculture organization

FCS: food consumption score

CSI: coping strategies index

DDS: dietary diversity score

HAZ: height-for-age Z-score

WAZ: weight-for-age Z-score

WHZ: weight-for-height Z-score 
medRxiv preprint doi: https://doi.org/10.1101/2021.07.27.21261221; this version posted July 30, 2021. The copyright holder for this preprint (which was not certified by peer review) is the author/funder, who has granted medRxiv a license to display the preprint in perpetuity. It is made available under a CC-BY-ND 4.0 International license.

\section{Declarations}

\section{Ethics approval and consent to participate}

Data were collected by the Lao Provincial Health Department as part of routine, nonresearch public health activities. We requested and obtained data from the Lao Provincial Health Department. Ethical clearance for secondary data analysis was obtained from the Research Ethics Committee in the University of Health Sciences within the Lao Ministry of Health and Committee for the Protection of Human Subjects within University of California, Berkeley (protocol ID: 2021-05-14365).

\section{Availability of data and materials}

Data is owned by the Luang Prabang Provincial Health Department and permission has been granted for its use.

\section{Competing interests}

$\mathrm{HC}, \mathrm{AV}$ and KK, were or are currently employees of Save the Children, International. Save the Children supports a government led Primary Health Care Program in Luang Prabang which includes nutritional interventions.

\section{Funding}

The survey was funded from the grants received by Save the Children Japan from Takeda Pharmaceutical Company Limited Global CSR Partnership.

\section{Authors' contributions}

$\mathrm{PC}, \mathrm{HC}$, and $\mathrm{JRH}$ conceptualized the research. $\mathrm{PC}$ and $\mathrm{HC}$ assisted in data collection. $\mathrm{PC}$ and JRH analyzed the data. $\mathrm{HC}$ and JRH wrote the manuscript. AV and KK lead the Save the Children health program in Luang Prabang and the Vientiane country office, respectively. All authors edited and read the manuscript.

\section{Acknowledgements}

We are grateful to Lilly Schofield and Yasir Arafat for their inputs on COVID related questions in preparing the survey and their review of the manuscript. We are grateful for the team of data collectors and supervisors who collected the data, to our study participants for their time and investment in the survey, and to the Luang Prabang Provincial Health Department for their continued partnership. 


\section{Summary Box}

What is already known?

The COVID-19 pandemic has disrupted food supply chains and livelihoods, causing concerns that a global nutrition crisis is imminent and prompting leaders from United Nations agencies to issue an immediate call to action to direct funds towards prevention of child malnutrition. While documented COVID-19 transmission in Lao PDR was lower than that of surrounding counties, malnutrition rates are high, particularly in the northern province of Luang Prabang, which is heavily reliant on tourism for livelihoods.

What are the new findings?

Nearly four-fifths of those interviewed in Luang Prabang Province, Lao PDR reported that it was harder to meet their household's food needs, compared to before the pandemic, with $51 \%$ attributing the reason to increased food prices. Over $85 \%$ of households reported losing income. Lower expenditures and increased difficulty obtaining food were both associated with lower household food consumption scores and higher household coping strategies, in adjusted analyses. Households who obtained a greater proportion of their foods through home production appeared more resilient than households who obtained a greater proportion of their foods through purchasing. What do the new findings imply?

The pandemic may deeply exacerbate food insecurity in Lao PDR, potentially leading to increases in child wasting. Increased local food production and establishment of safety net programs that offset income losses may be two strategies that address this problem among this population. 
medRxiv preprint doi: https://doi.org/10.1101/2021.07.27.21261221; this version posted July 30, 2021. The copyright holder for this preprint

(which was not certified by peer review) is the author/funder, who has granted medRxiv a license to display the preprint in perpetuity.

It is made available under a CC-BY-ND 4.0 International license .

\section{Introduction}

Disruptions to food, economics, and health systems during the COVID-19 pandemic are expected to increase the risk of malnutrition among low- and middleincome countries (LMICs) [1-4]. The food supply chain has faced challenges across multiple stages, including loss of labor for agricultural production and postharvest handling due to movement restrictions or illnesses; closure of processing and distributing facilities; disruptions in distribution networks under restricted trade policies; and changes in consumer demand and market access [5]. Such challenges have resulted in increases in food prices, with the Food and Agricultural Organization (FAO) reporting that wheat and rice prices increased by $8 \%$ and $25 \%$, respectively, between March 2019 and April 2020 [6]. Economic disruptions, such as business closures and declines in tourism, are simultaneously expected to reduce country-specific gross national incomes (GNI) by around $8 \%$ in most LMICs [7]. Losses in income are expected to push an additional 1.4 million people into extreme poverty, classified as earning less than $\$ 1.90$ per day [7]. Overall, the World Food Programme projects that the number of people in LMICs who are food insecure will double, from 135 million in 2019 to 265 million by the end of 2020 [8]. Compounding this effect, health services designed to catch and treat acute malnutrition may be disrupted in many LMICs. For instance, UNICEF estimates a reduction of $30 \%$ in the coverage of essential nutrition services in LMICs due to difficulties in mobility of both users and providers, interruption of non-COVID-19 services in communities, higher burdens on the health care workers, and limited personal protective equipment [9]. 
medRxiv preprint doi: https://doi.org/10.1101/2021.07.27.21261221; this version posted July 30, 2021. The copyright holder for this preprint

Increased food insecurity coupled with a decline in access to essential nutritional services is expected to lead to increases in the prevalence of childhood wasting, an acute form of malnutrition associated with elevated risk of mortality [10,11]. One study estimates that there could be a $14.3 \%$ increase in the prevalence of moderate or severe wasting among children younger than five years in the 118 LMICs due to COVID-19related income losses [2]. By another projection, an increase in wasting of this order of magnitude (10-50\%), coupled with a decline in maternal and child health services by 9.8-15.9\%, would be associated with an increase of $9.8-44.7 \%$ in under-five deaths per month [12]. To prevent a global malnutrition crisis, leaders from four United Nations agencies (UNHCR, UNICEF, FAO, WHO) have issued an immediate call to action, recommending $\$ 2.4$ billion be directed to avoiding child malnutrition through wasting treatment and prevention, vitamin A supplementation, and breastfeeding support [13]. Alongside these efforts, leaders have called for research that estimates the scale and reach of nutrition challenges, including country-specific estimates of the effect of the pandemic on incomes, and the ability to meet food needs and access health services.

Lao People's Democratic Republic (PDR) has one of the highest rates of malnutrition in southeast Asia, with a national prevalence of stunting of 33\%, underweight of $21 \%$ and wasting of $9 \%$ [14]. Lao PDR experienced its first case of COVID-19 infection in March 2020 [15]. Shortly afterwards, the government imposed a strict lockdown for six weeks, stopping human movement between districts, provinces, and across the border. A total of six cases were identified between March and April 2020. Beginning in May 2020, restrictions on within-country movement eased along with adherence to protective measures (e.g., mask wearing and social distancing), but 
medRxiv preprint doi: https://doi.org/10.1101/2021.07.27.21261221; this version posted July 30, 2021. The copyright holder for this preprint

borders remain closed to everyone except those who entered the country via special mission flights, who must undergo strict quarantine and testing in government authorised facility [16]. Between March 2020 and February 2021, only 45 cases had been reported in Lao PDR, mainly among individuals returning to the country [17]. In April 2021, a second outbreak of COVID-19 occurred that spread quickly during New Year celebrations. A second lockdown was imposed on April $25^{\text {th }}$ with provincial and district travel restricted, surveillance on closed country borders increased, and testing and contact tracing efforts increased. Between April 1, 2021 and June 1, 2021, over 1,800 cases were confirmed, the majority in the capital city, Vientiane, with the first confirmed death from COVID-19 occurring in May of 2021 [17].

While Lao PDR has reported fewer cases of COVID-19 than its neighbouring countries, it may experience substantial economic and food security effects of the pandemic. The FAO reports that food prices in Lao PDR have increased by $7.1 \%$ between February 14, 2020 to January 30, 2021 [18]. At the same time, the Ministry of Labour and Social Welfare reported a surge in unemployment from $2 \%$ before the pandemic to $25 \%$ as of May 2020 [19]. Moreover, in a national assessment, UNICEF found that between August 2019 and August 2020, there was a 10-24\% decline in the coverage of maternal health services, newborn services, routine vaccinations, screening for child wasting, and treatment of child wasting [9]. The economic effects of the pandemic are expected to be felt most strongly in Luang Prabang province, a popular tourist destination. In 2019, Luang Prabang received about 638,000 international visitors and 222,000 domestic tourists. In May 2020, 78\% of Luang Prabang's tourism enterprises were closed, and those that remained open did so largely at partial capacity 
medRxiv preprint doi: https://doi.org/10.1101/2021.07.27.21261221; this version posted July 30, 2021. The copyright holder for this preprint

(which was not certified by peer review) is the author/funder, who has granted medRxiv a license to display the preprint in perpetuity.

It is made available under a CC-BY-ND 4.0 International license.

[20]. This is particularly concerning, as the Luang Prabang province bears a disproportionate burden of children who are stunted (41.3\%) or underweight (25\%) [14].

In rural provinces of Luang Prabang where documented COVID-19 transmission was low, we aimed to 1) assess the relative difficulty in meeting food needs and accessing health care during the COVID-19 pandemic compared to before the pandemic;2) compare self-reported difficulty in meeting food needs to indicators of food security among women, children and the household; 3) identify strategies associated with increased resiliency to food insecurity.

\section{Methods}

Survey region and population

We obtained data on a cross sectional, household survey from the Lao Provincial Health Department. Data were collected as part of the Lao Health Department's endline evaluation of the Primary Health Care Program to monitor and evaluate public health activities over a three-year period, starting in 2017. Data were collected from three districts - Nan, NamBak, and Pak Ou - in Luang Prabang Province. These districts have a high prevalence of ethnic minorities, particularly Hmong and Khmu ethnicities. Livelihoods are largely agriculturally based.

\section{Sampling plan}

The target overall sample size was 1,200 households. The sample size was chosen to detect with $95 \%$ confidence and $80 \%$ power a change from $77.7 \%$ to $83 \%$ in the proportion of women delivering with a skilled birth attendant since the baseline survey in 2017 , accounting for a design effect of 1.5 and a non-response rate of $5 \%$. A 
medRxiv preprint doi: https://doi.org/10.1101/2021.07.27.21261221; this version posted July 30, 2021. The copyright holder for this preprint

(which was not certified by peer review) is the author/funder, who has granted medRxiv a license to display the preprint in perpetuity.

It is made available under a CC-BY-ND 4.0 International license.

household was considered eligible for selection if members have lived in the village for at least two years, if it contained a child under the age of five, and if an adult respondent provided verbal, informed consent to participate.

Household selection followed a multistage clustered sampling design that stratified by the three districts. In the first stage, 25 villages were selected using probability proportional to size sampling. In the second stage, 30 households per village were selected using simple random sampling from a list of eligible households prepared by the village head in collaboration with the village health volunteer. The health and diet of one child under the age of five per household was assessed, and anthropometric measurements taken. If there were more than one child under five years in the house, a third stage of sampling was used, in which one child was selected using simple random sampling.

\section{Household questionnaire}

Household questionnaires were administered verbally by trained data collectors. Information of household demographics, household food security, maternal and child diet, child anthropometrics, and self-reported changes in food access, income, expenditures and access to health services during the pandemic were collected. The survey was translated into Lao language, and back translated to ensure correct translation. One enumerator per team was also fluent in the local languages of Khmu and Hmong, in case the respondent did not speak Lao. A copy of the reduced survey tool is included in the Supplemental Info. 
medRxiv preprint doi: https://doi.org/10.1101/2021.07.27.21261221; this version posted July 30, 2021. The copyright holder for this preprint

The endline survey used the same questionnaire as the baseline survey, which was adapted from global standard reproductive, maternal, newborn and child health and nutrition surveys, and added questions related to food security and access to health services during the pandemic. These additional questions were adapted from a standardized questionnaire developed by Save the Children, International to assess the impact of COVID-19 globally [21]. Respondents were asked if, compared to before the pandemic, it was much harder, somewhat harder, easier, or the same to meet their family's food needs. If harder, families were asked to list the reasons why. Similarly, respondents were asked if, compared to before the pandemic, it was much harder, somewhat harder, easier, or the same to access health care. Finally, families were asked if they lost income or reduced their expenditures during the pandemic, and if so, asked to estimate by what percent.

\section{Calculation of household food security and maternal and child dietary diversity}

Household food security was assessed through two standard indicators: the food consumption score and coping strategy index. The food consumption score (FCS) is a frequency weighted household dietary diversity score calculated by multiplying the frequency of consumption of different food groups consumed by a household during the 7 days before the survey by a weighting factor, and summing [22]. The food groups, and their respective weights include: main staples (2), pulses (3), vegetables (1), fruit (1), meat and fish (4), dairy (4), sugar (0.5), and oils/butter (0.5). Higher scores indicate better food security.

The Coping Strategies Index (CSI) was also used to compare household food security. CSI is calculated by multiplying the weekly frequency of five behaviors by the 
medRxiv preprint doi: https://doi.org/10.1101/2021.07.27.21261221; this version posted July 30, 2021. The copyright holder for this preprint

(which was not certified by peer review) is the author/funder, who has granted medRxiv a license to display the preprint in perpetuity.

It is made available under a CC-BY-ND 4.0 International license .

weight of the behavior and summing for all behaviors [23]. The five standard coping strategies and their severity weightings are: Eating less-preferred foods (1.0); Borrowing food/money from friends and relatives (2.0); Limiting portions at mealtime (1.0); Limiting adult intake (3.0), and reducing the number of meals per day (1.0). Lower scores indicate better food security. The CSI has good agreement with other indicators of household food insecurity, including the household food insecurity and access scale [24].

In addition, we calculated an individual dietary diversity score (DDS) for women and children aged 6-59 months [25]. DDS for children aged 24-59 months is calculated by summing the total number of food groups consumed in the previous 24 hours, where the food groups are defined as: grains, roots and white tubers; legumes and nuts; dairy products; meat; eggs; vitamin A-containing fruits and vegetables (i.e., dark-green, leafy vegetables, fruits that are orange on the inside); other fruits and vegetables. The child must consume at least four of the seven food groups to meet their minimum acceptable dietary diversity [25]. For children aged 6-23 months, breastmilk is added as an eighth food group and the child must consume five out of eight food groups to meet minimum acceptable dietary diversity.

DDS for women is tallied by adding up the number of food groups consumed out of the following ten groups: grains, roots, and white tubers; legumes; nuts and seeds; dairy products; meat; eggs; dark, leafy greens and vegetables; other vitamin-A-rich fruits and vegetables; other vegetables; other fruits. The woman must consume at least five of the ten food groups to meet her minimum dietary diversity [25]. Women who 
medRxiv preprint doi: https://doi.org/10.1101/2021.07.27.21261221; this version posted July 30, 2021. The copyright holder for this preprint

(which was not certified by peer review) is the author/funder, who has granted medRxiv a license to display the preprint in perpetuity.

It is made available under a CC-BY-ND 4.0 International license .

reported having an abnormal diet (i.e., ate much more or much less than normal) in the past 24 hours were excluded from analysis.

Anthropometric analysis

Weight and height of children were recorded to the nearest $0.01 \mathrm{~kg}$ and $0.1 \mathrm{~cm}$, respectively. Weight-for-age (WAZ), height-for-age (HAZ), and weight-for-height (WHZ) Z-scores were determined using 2006 WHO Growth Standards [26]. A child was considered stunted, wasted, or underweight if they had a WAZ, WHZ, or WAZ score below -2SD, respectively. The degree to which even small changes to body weight will translate into changes in the proportion of children classified as underweight or wasted varies between populations, as it depends on the density of Z-scores clustered around the dichotomous classification threshold of -2SD [27]. As undernutrition prevalence is a key indicator used to monitor progress and allocate nutrition and other health services, we considered the theoretical implications of increased food insecurity on undernutrition prevalence in our population. We examined the change in childhood undernutrition in our study population to a simulated reduction in bodyweight. Following prior study, we presumed potential COVID-19 associated shocks to range between a $0.5 \%$ and $1 \%$ reduction in bodyweight [27]. We simulated a reduction of $0.5 \%$ and $1 \%$ by multiplying child weight by 0.995 and 0.99 , respectively, and recalculated the WAZ and WHZ scores under this simulated weight.

Statistical analysis

Data were analyzed in $\mathrm{R}$ version 3.5 [28]. Survey weights were calculated using the inverse probability of selection for a child (for child outcome) or a household (for 
medRxiv preprint doi: https://doi.org/10.1101/2021.07.27.21261221; this version posted July 30, 2021. The copyright holder for this preprint

household or maternal outcomes). The survey package in $\mathrm{R}$ was used to calculate means and percentages accounting for survey weights, and standard errors used to calculate 95\% confidence intervals were determined accounting for clustering [29]. Univariate and multivariate associations were assessed using generalized linear models, accounting for survey weights, and using cluster robust standard errors to adjust for clustering at the village level. A directed-acyclic-graph (DAG) was used to identify variables that may confound the relationship between pandemic-associated changes and household food security, where a confounder is defined as a variable associated with the exposure, causally associated with the outcome, and not on the causal pathway between exposure and outcome. Multivariate models examining the relationship between pandemic-associated changes and household food security included fixed effects for potential confounding factors of household ethnicity, household size, education level of mother and the head of household, and district. Adjusted models for maternal outcomes additionally included mother's age, and models for children outcomes additionally included child's age and sex.

\section{Ethics}

Data were collected by the Lao Provincial Health Department as part of routine, non-research public health activities. We obtained data from the Lao Provincial Health Department. Ethical clearance for secondary data analysis was obtained from the Research Ethics Committee in the University of Health Sciences within the Lao Ministry of Health and Committee for the Protection of Human Subjects within University of California, Berkeley (protocol ID: 2021-05-14365). 
medRxiv preprint doi: https://doi.org/10.1101/2021.07.27.21261221; this version posted July 30, 2021. The copyright holder for this preprint (which was not certified by peer review) is the author/funder, who has granted medRxiv a license to display the preprint in perpetuity. It is made available under a CC-BY-ND 4.0 International license .

\section{Public Involvement}

Community members were involved in the conduct of this research. During the survey, community volunteers assisted in locating other community members for participation in the survey. Community members were informed of the results of this study during one of their monthly village health days. The results were conveyed verbally and with posters by the village health volunteers.

\section{Results}

Interviews were completed for 1,122 households, corresponding to a $93.5 \%$ response rate. Reasons for non-response included empty house (53.8\%), parent not at home (38.5\%) and inaccessible house (5.1\%). The most common ethnicities of those interviewed were Khmu (463, 41.3\%), Lao Lom (340, 30.3\%), and Hmong (281, 25.0\%). Undernutrition among children under five years in the study region was high, with the survey-weighted prevalence of wasting at $4.5 \%(95 \% \mathrm{Cl}: 3.5,5.8)$, underweight at $18.2 \%$ (95\% Cl: 15.9, 20.7\%), and stunting at 32.9\% (95\% Cl: 29.6, 36.4\%).

\section{Food security}

Nearly four-fifths $(78.5 \%)$ of the study population reported that it was harder to meet their family's food needs during the pandemic, as compared to before (Table 1). A weighted $60.9 \%(95 \% \mathrm{Cl}: 57.6,64.1 \%)$ of individuals reported that it was somewhat harder to meet food needs, while $17.6 \%$ (95\% Cl: 15.4, 20.0\%) reported that it was much harder. Among the 874 individuals who found it harder to meet food needs, the most common reason reported was that foods were more expensive (51.2\%), followed by household losing income (45.3\%), food not available at markets (36.6\%), and 
medRxiv preprint doi: https://doi.org/10.1101/2021.07.27.21261221; this version posted July 30, 2021. The copyright holder for this preprint (which was not certified by peer review) is the author/funder, who has granted medRxiv a license to display the preprint in perpetuity.

It is made available under a CC-BY-ND 4.0 International license .

markets being closed (36.5\%). The median monthly expenditure among households was US $\$ 133$. Households spent, on average, $40 \%$ of their income on food, which was increased from $30 \%$ in 2017.

Table 1. Self-reported effects of the pandemic on household access to food, health care, and income.

\begin{tabular}{|c|c|c|}
\hline & $\begin{array}{c}\text { Weighted percentage } \\
\text { (95\% Confidence interval) }\end{array}$ & $\mathbf{N}$ \\
\hline \multicolumn{3}{|c|}{ Relative ability to meet family's food needs now compared to before the pandemic ( $N=1120)$} \\
\hline Easier & $0.83(0.38,1.82)$ & 8 \\
\hline No change & $20.7(18.3,23.3)$ & 238 \\
\hline Somewhat harder & $60.9(57.6,64.1)$ & 698 \\
\hline Much harder & $17.6(15.4,20.0)$ & 176 \\
\hline \multicolumn{3}{|c|}{ Reasons it is harder to meet food needs during the pandemic $(\mathbf{N}=874)$} \\
\hline Items more expensive & $51.2(46.4,56.0)$ & 415 \\
\hline Household lost income & $45.3(40.9,49.9)$ & 465 \\
\hline Less food is available & $36.6(33.1,40.2)$ & 561 \\
\hline Markets are closed & $36.5(32.3,41.0)$ & 555 \\
\hline \multicolumn{3}{|c|}{ Proportion of household income lost during the pandemic $(\mathrm{N}=1122)$} \\
\hline No income lost & $14.4(12.3,16.6)$ & 165 \\
\hline $1-25 \%$ & $17.5(14.6,20.7)$ & 192 \\
\hline $26-50 \%$ & $54.4(51.3,57.4)$ & 607 \\
\hline $51-75 \%$ & $9.2(1.7,11.2)$ & 104 \\
\hline $76-100 \%$ & $4.6(3.5,6.1)$ & 54 \\
\hline \multicolumn{3}{|c|}{ Percent reduction in household expenditures during the pandemic $(\mathrm{N}=1122)$} \\
\hline No reduction & $36.3(33.2,39.6)$ & 415 \\
\hline $1-25 \%$ & $23.2(19.4,27.4)$ & 257 \\
\hline $26-50 \%$ & $35.7(32.9,38.6)$ & 400 \\
\hline $51-75 \%$ & $3.9(2.9,5.3)$ & 41 \\
\hline $76-100 \%$ & $0.89(0.44,1.8)$ & 9 \\
\hline \multicolumn{3}{|c|}{ Relative ability to access health care now compared to before the pandemic $(\mathrm{N}=1121)$} \\
\hline Easier & $0.40(0.15,1.09)$ & 8 \\
\hline No change & $47.0(44.0,50.0)$ & 544 \\
\hline Somewhat harder & $37.4(34.6,40.2)$ & 413 \\
\hline Much harder & $4.8(3.7,6.1)$ & 48 \\
\hline Undecided & $10.0(7.5,13.1)$ & 108 \\
\hline
\end{tabular}

The mean food consumption score was 60.9 (95\% Cl: 59.7, 62.3) (Table 2). Households consumed rice daily and meat and vegetables an average of 3.0 and 4.8 days per week, respectively. On average, children consumed 4.21 (95\% Cl: $3.95,4.18)$ food groups in the day prior to the survey, corresponding to $62.5 \%(95 \% \mathrm{Cl}: 59.1,65.8)$ 
medRxiv preprint doi: https://doi.org/10.1101/2021.07.27.21261221; this version posted July 30, 2021. The copyright holder for this preprint (which was not certified by peer review) is the author/funder, who has granted medRxiv a license to display the preprint in perpetuity. It is made available under a CC-BY-ND 4.0 International license .

of children that met the minimum DDS requirement. Women consumed an average of 5.38 (95\% Cl: 5.25, 5.51) food groups, corresponding to $67.7 \%(95 \% \mathrm{Cl}: 64.4,70.9)$ meeting her minimum DDS. Compared to 2017, households in 2020 demonstrated significantly $(p<0.05)$ lower dietary diversity and household food security. In $2017,76 \%$ of women and $69 \%$ of children met their minimum dietary diversity score, and the average CSI for households was 0.7 points lower. There was no change in household FCS from 2017 to 2020.

The distribution of both household food security indicators differed by whether or not households found it harder to access food during the pandemic (Figure 1). Among households who found it harder to meet their food needs during the pandemic, there was greater density of lower FCS (indicating worse food security) and higher CSI (indicating worse food security) compared to those who experienced no change. These relationships between household FCS and access to food during the pandemic were also seen in multivariate regression analyses (Table 2; Figure 2). Adjusting for ethnicity of the household, size of the household, district, and education level of the mother and head of household, we estimated that the average food consumption score among households who found it harder to meet their food needs was 2.74 points lower (95\% Cl: $0.55,4.92)$ than the average food consumption score among households who experienced no change (Figure 2). This is roughly equivalent to consuming vegetables nearly three fewer times per week, or consuming rice one less time per week. The household coping strategies index among households who had a harder time meeting their food needs was higher, indicating lower food security, but not significantly so. Dietary diversity scores for women and children were lower among households who had 
medRxiv preprint doi: https://doi.org/10.1101/2021.07.27.21261221; this version posted July 30, 2021. The copyright holder for this preprint (which was not certified by peer review) is the author/funder, who has granted medRxiv a license to display the preprint in perpetuity.

It is made available under a CC-BY-ND 4.0 International license .

more difficulty meeting their food needs during the pandemic, but not significantly so in adjusted analyses.

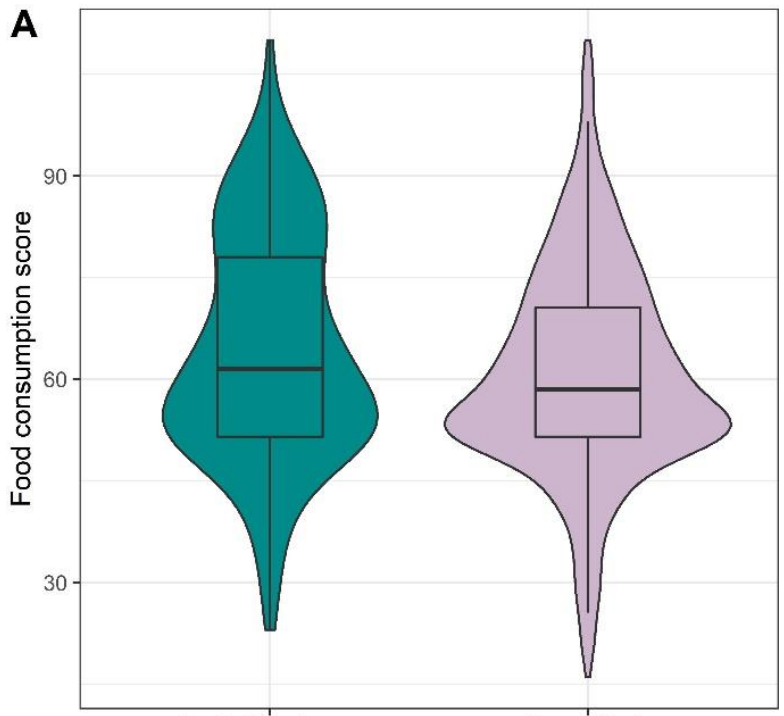

Easier/No change

Relative difficulty meeting household food needs

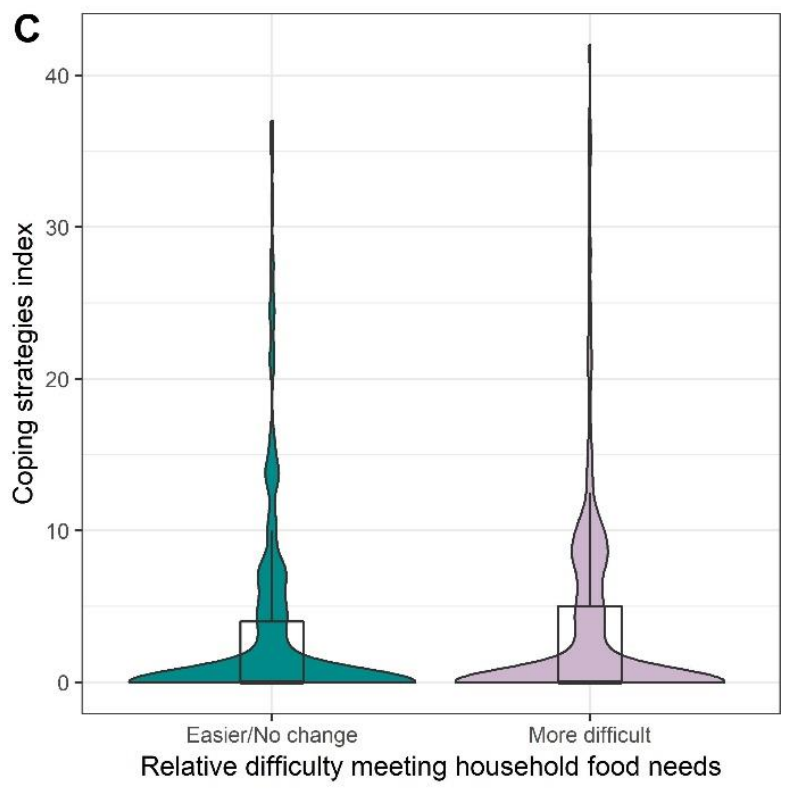

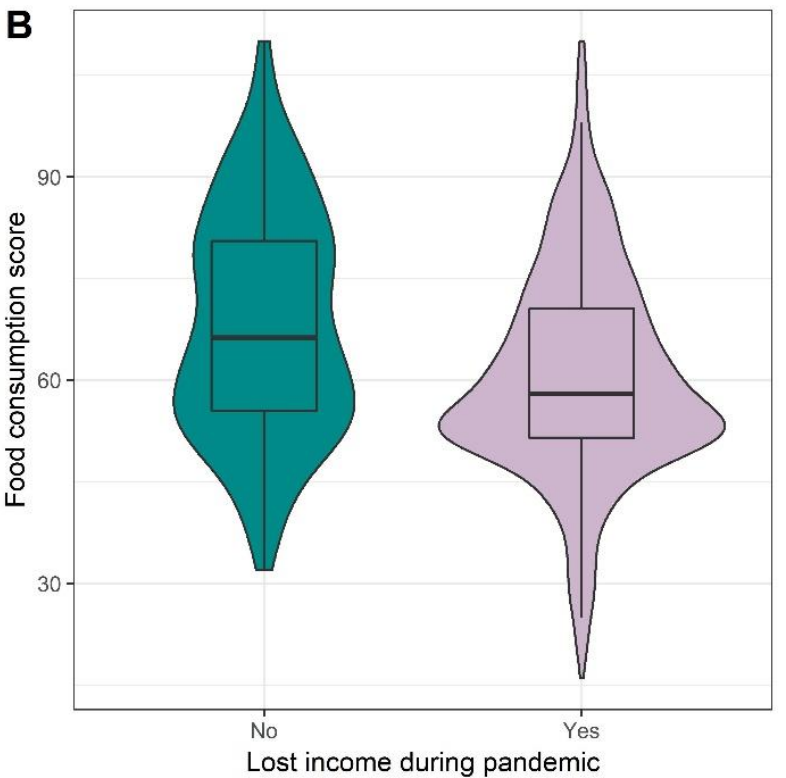

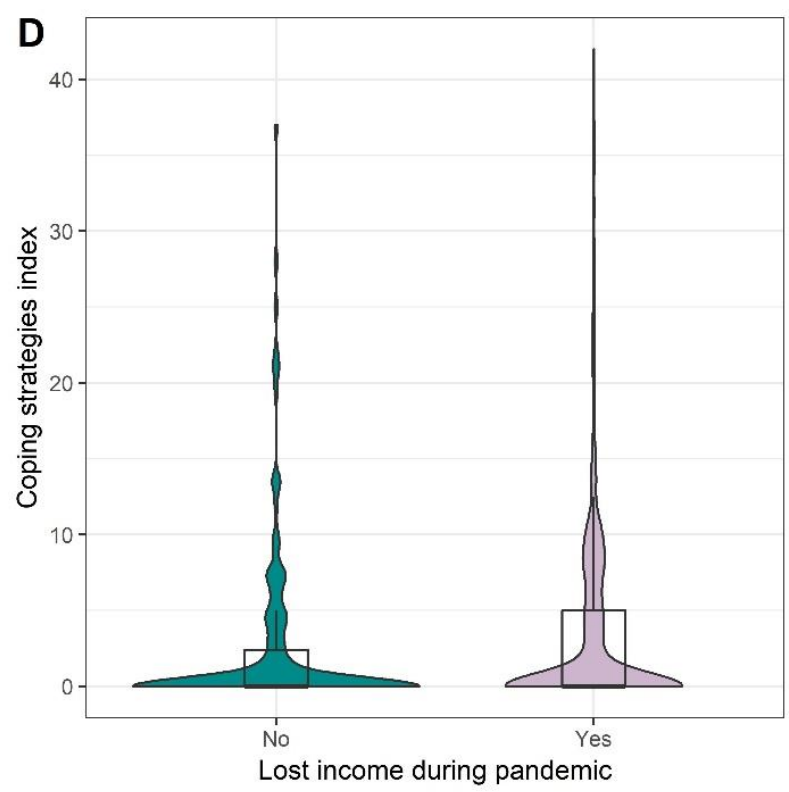

Figure 1. Violin plot showing distribution of two household food security measures, together with their median and interquartile range (IQR). Household food security was measured through food consumption score (FCS) (A, B) and coping strategies index (CSI) (C, D). Food insecurity is associated with low FCS and high CSI. 
Table 2. Model coefficients representing difference in food security indicator between households who self-reported that it is harder to access food during the pandemic compared those who reported no change/easier; and those who decreased spending during the pandemic and those who did not. Adjusted models for households control for household ethnicity, household size, education level of mother and the head of household, and district. Adjusted models for mothers include additionally mother's age. Adjusted models for children include additionally child's age and sex. FCS = food consumption score; CSI = coping strategy index; DDS = dietary diversity score. Lower values for FCS and DDS and higher values of CSI indicate greater food insecurity.

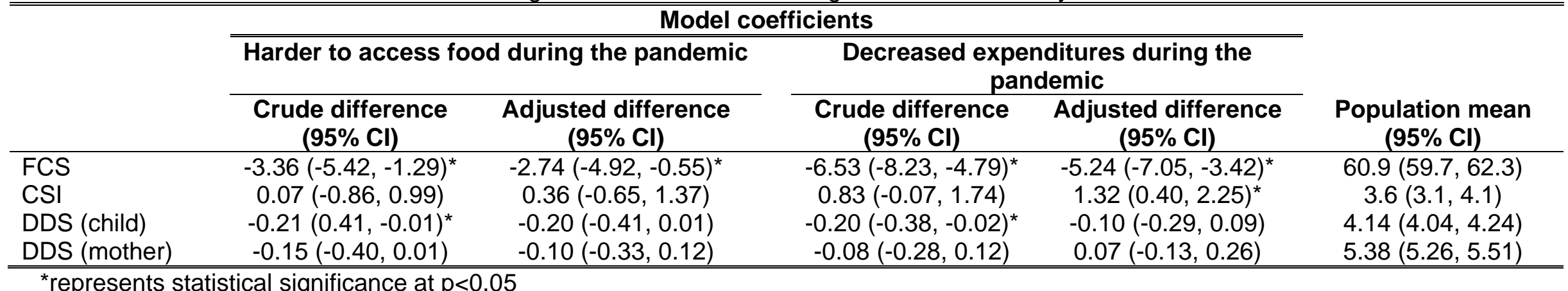

${ }^{*}$ represents statistical significance at $\mathrm{p}<0.05$ 
medRxiv preprint doi: https://doi.org/10.1101/2021.07.27.21261221; this version posted July 30, 2021. The copyright holder for this preprint (which was not certified by peer review) is the author/funder, who has granted medRxiv a license to display the preprint in perpetuity.

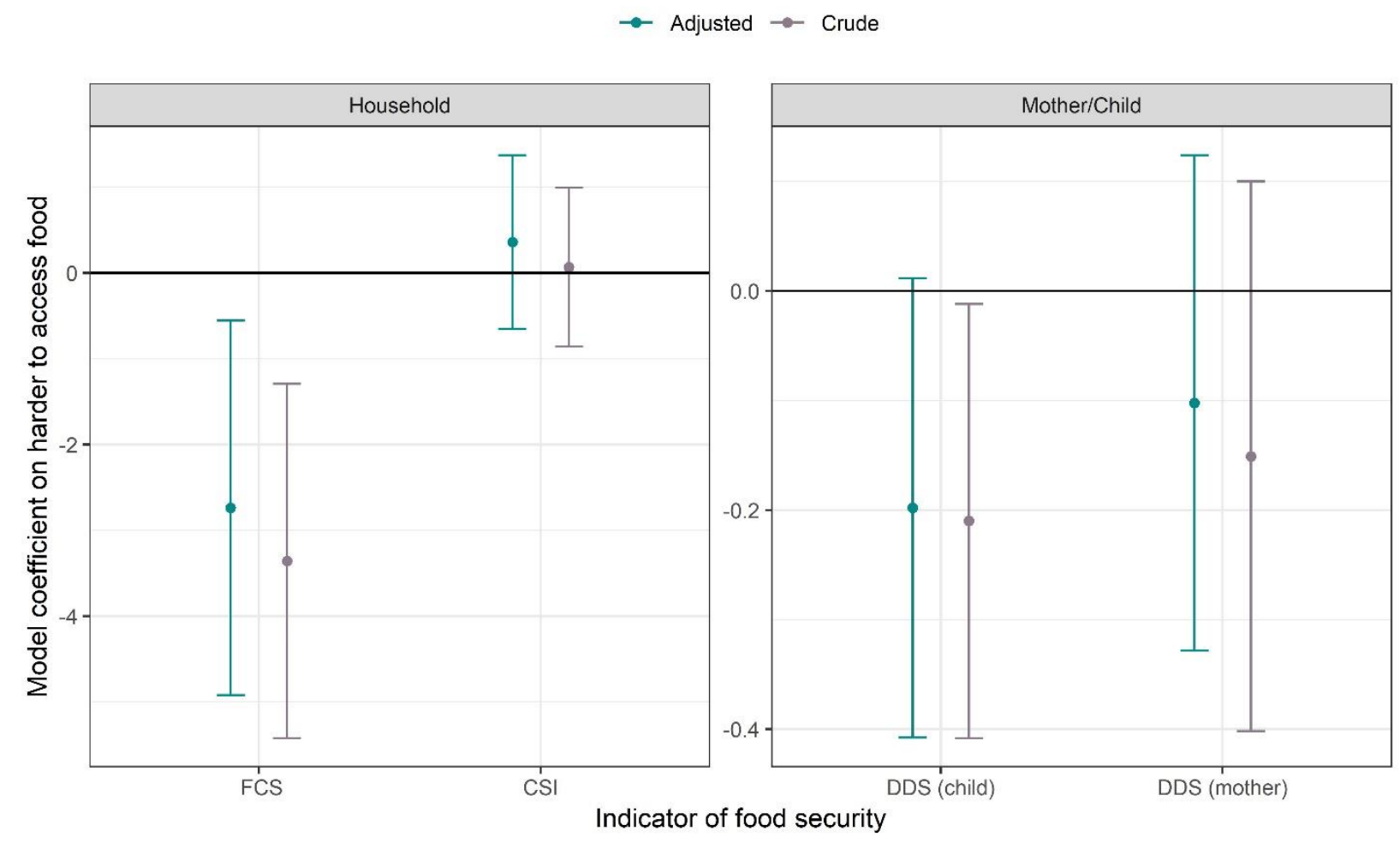

Figure 2. The difference in mean of food security indicator among households who had a harder time meeting their food needs during the pandemic compared to those who did not. Vertical bars represent $95 \%$ confidence intervals. Adjusted models for households control for household ethnicity, household size, education level of mother and the head of household, and district. Adjusted models for mothers include additionally mother's age. Adjusted models for children include additionally child's age and sex. FCS = food consumption score; CSI = coping strategy index; DDS = dietary diversity score. Lower values for FCS and DDS and higher values of CSI indicate greater food insecurity.

Resiliency to food insecurity

We estimated the percentage of a household's food sources in the past week that was self-produced (e.g., farmed, fished, hunted, gathered). On average, families met $42 \%$ of their food needs through self-production (interquartile range: $27 \%, 57 \%$ ). Commonly self-produced foods included: insects, aquatic animals other than fish, mushrooms, and roots (Figure 3). Over half of households also self-produced rice and 
medRxiv preprint doi: https://doi.org/10.1101/2021.07.27.21261221; this version posted July 30, 2021. The copyright holder for this preprint (which was not certified by peer review) is the author/funder, who has granted medRxiv a license to display the preprint in perpetuity.

It is made available under a CC-BY-ND 4.0 International license .

vegetables, and about one quarter self-produced fish, meat, and fruits. We found that households who derived a greater proportion of their food needs through homegrown methods were more resilient than families who purchased their foods. Adjusting for ethnicity of the household, size of the household, district, and education level of the mother and head of household, we estimated that the average percentage of food obtained from homegrown methods was $4.22 \%$ (95\% Cl: $1.28,7.15 \%)$ lower among households who found it harder to meet their food needs compared to household who experienced no change. Persons who found it harder to meet their food needs during the pandemic also spent fewer hours per week fishing, gathering, or hunting, though the results were not significant.

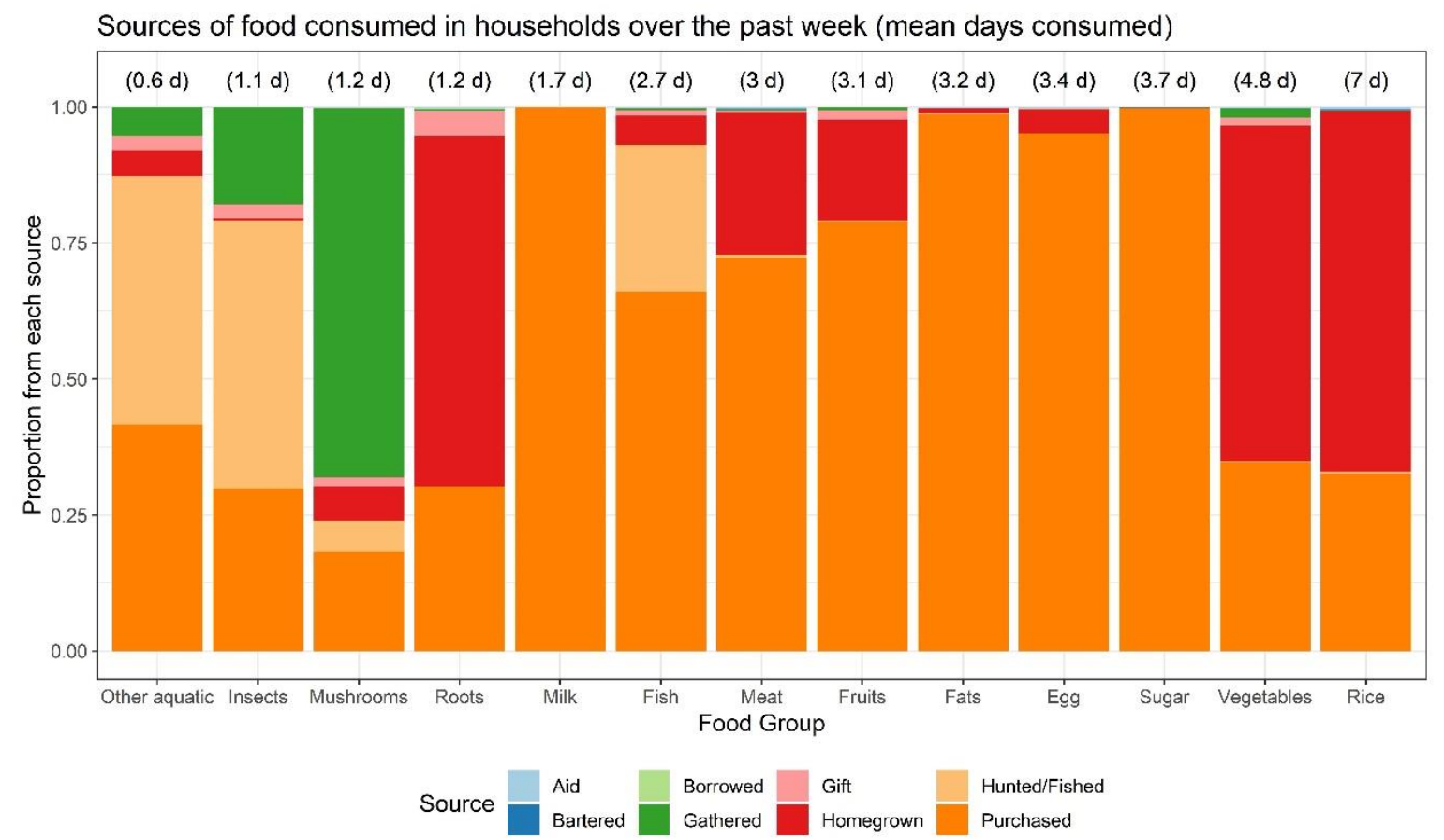

Figure 3. Proportional source of each food group consumed during the past week by households. Numbers in parenthesis above the bars indicates the mean number of days per week household consumed these food groups. 
medRxiv preprint doi: https://doi.org/10.1101/2021.07.27.21261221; this version posted July 30, 2021. The copyright holder for this preprint (which was not certified by peer review) is the author/funder, who has granted medRxiv a license to display the preprint in perpetuity. It is made available under a CC-BY-ND 4.0 International license .

Income and expenditures

Over $85 \%$ of the study population reported losing income during the pandemic, with the majority of respondents $(54.4 \%, 95 \% \mathrm{Cl}: 51.3,57.4 \%)$ reporting losing between $25-50 \%$ of their income. Households who reported declines in income were more likely to reduce spending, with the greater the reduction in income corresponding to greater reductions in household expenditures (Figure 4a). A weighted 23.3\% reported reducing household expenditures by $1-25 \%$, while $35.7 \%$ reported reducing expenditures by 25 $50 \%$. The distribution of both household food security indicators also differed by whether or not households lost income during the pandemic (Figure 1).
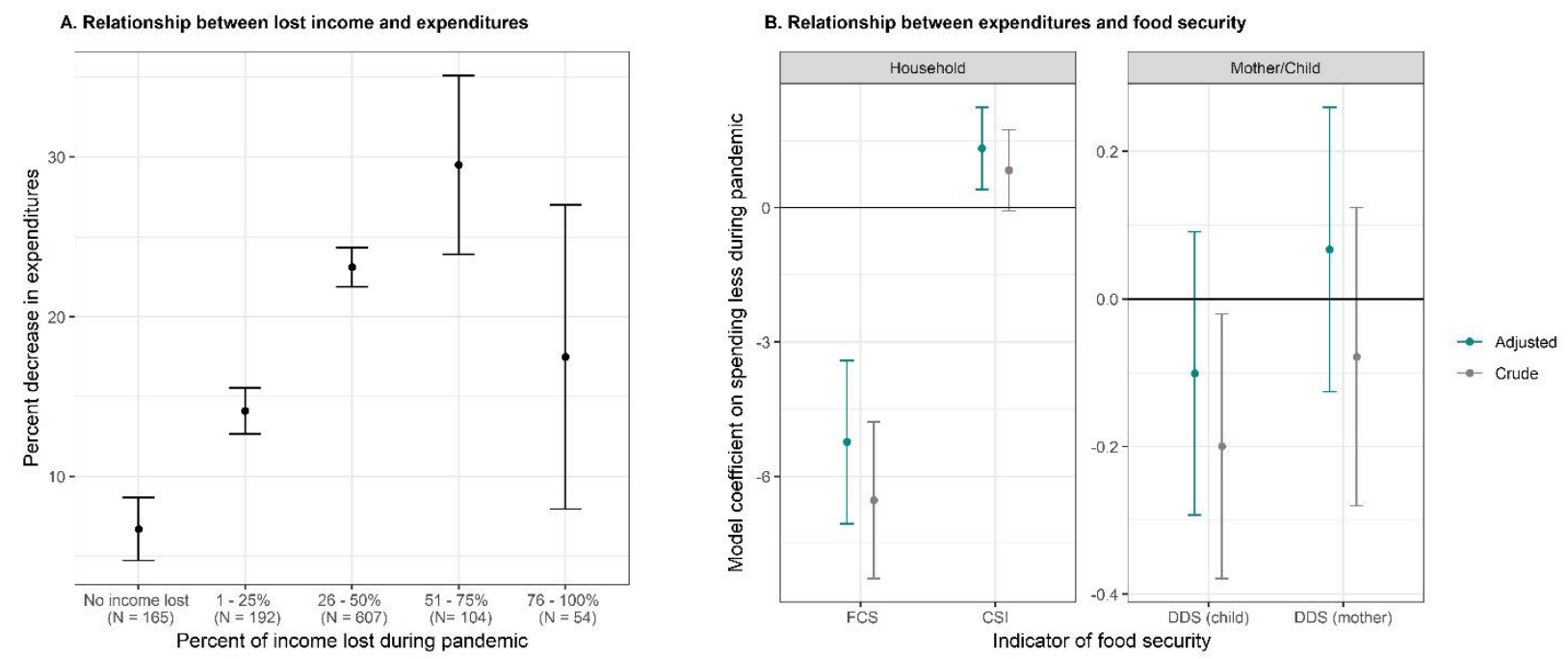

Figure 4. A) Mean decrease in expenditures reported, stratified by the percent reduction in household income. Vertical bars represent $95 \%$ confidence intervals. B) The difference in mean of food security indicator among households who reduced spending during the pandemic compared to those who did not. Vertical bars represent $95 \%$ confidence intervals. Adjusted models for households control for household ethnicity, household size, education level of mother and the head of household, and district. Adjusted models for mothers include additionally mother's age. Adjusted models for children include additionally child's age and sex. FCS = food consumption score; $\mathrm{CSI}$ = coping strategy index; DDS = dietary diversity score. Lower values for FCS and DDS and higher values of CSI indicate greater food insecurity. 
medRxiv preprint doi: https://doi.org/10.1101/2021.07.27.21261221; this version posted July 30, 2021. The copyright holder for this preprint

Households who reduced expenditures during the pandemic had significantly decreased food security in adjusted analyses, as measured by the FCS, and significantly decreased food security in univariate analyses as measured by the FCS, CSI, and child's DDS (Figure 4b, Table 2). In adjusted analyses, families who reported spending less during the pandemic had a household FCS that was $5.23(95 \% \mathrm{Cl}: 3.41$, 7.05) units lower, and a CSI that was $0.83(95 \% \mathrm{Cl}:-0.07,1.74)$ units higher than families who did not reduce spending. Dietary diversity scores for children were lower among households who had more difficulty meeting their food needs during the pandemic, but not significantly so in adjusted analyses.

Access to health care

A weighted $37.4 \%(95 \% \mathrm{Cl}: 34.6,40.2 \%)$ of individuals reported that it was somewhat harder to access healthcare compared to before the pandemic, while $4.8 \%$ (95\% Cl: 3.7, 6.1\%) reported that it was much harder (Table 1). We identified $123(11 \%)$ women and 557 (50\%) children who had experienced fever, diarrhea, or respiratory infection in the two weeks prior to the survey. Of these, a weighted $69.7 \%(95 \% \mathrm{Cl}$ : $66.3,73.0 \%)$ of children and $81.2 \%(95 \% \mathrm{Cl}: 73.3,87.2)$ of women sought care from a health facility. We found no association between healthcare seeking behavior and relative ability to access health care.

Sensitivity of undernutrition prevalence to small shocks in bodyweight

We did not find any difference in WAZ or WHZ scores among children from households who experienced greater difficulty meeting their food needs or among children from households who lost income or reduced spending. We examined the 
medRxiv preprint doi: https://doi.org/10.1101/2021.07.27.21261221; this version posted July 30, 2021. The copyright holder for this preprint (which was not certified by peer review) is the author/funder, who has granted medRxiv a license to display the preprint in perpetuity. It is made available under a CC-BY-ND 4.0 International license.

change in the proportion of children classified as wasted or underweight under simulated shocks in which bodyweight decreased by $0.5 \%$ and $1 \%$. In the study population, we observed a prevalence of wasting of $4.5 \%$. If bodyweight were to decrease by $0.5 \%$ or $1 \%$, we estimated a prevalence of wasting of $6.2 \%$ and $6.6 \%$, respectively, in our population (Figure 5). In other words, a decrease in bodyweight by $0.5-1 \%$ would be associated with a disproportionate increase in wasting of $1.7-2.1$ percentage points in our study population. Similarly, we observed a prevalence of underweight of $18.2 \%$. If bodyweight were to decrease by $0.5 \%$ or $1 \%$, we estimated a prevalence of underweight of $19.0 \%$ and $20.5 \%$, respectively. Therefore, a decrease in bodyweight by only $0.5-1 \%$ would be associated with an increase in underweight of $0.8-2.3$ percentage points in our study population.

Bodyweight

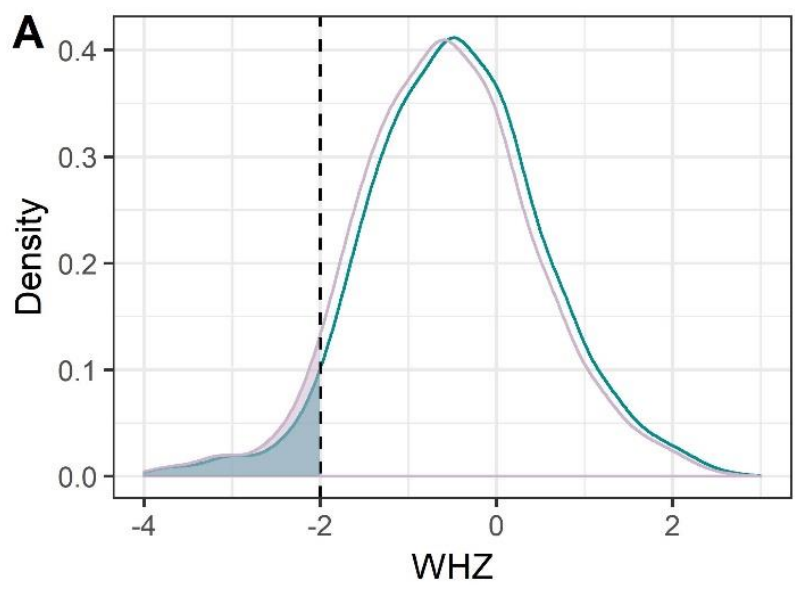

simulated $1 \%$ reduction

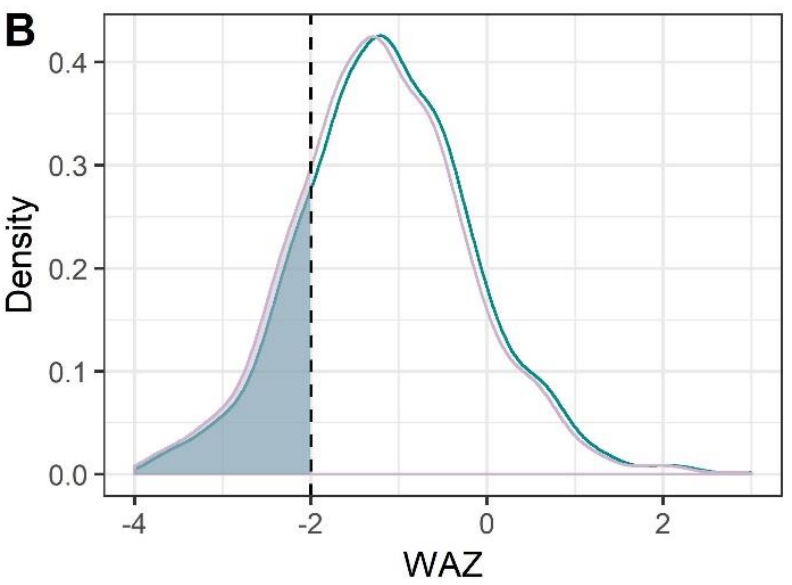

Figure 5. WHZ and WAZ curves among children under 5 under observed (cyan) conditions and under a simulated shock in which body weight reduces by $1 \%$ (pink). Area shaded to the left of 2 represents the proportion of children classified as wasted or underweight, respectively. 
medRxiv preprint doi: https://doi.org/10.1101/2021.07.27.21261221; this version posted July 30, 2021. The copyright holder for this preprint

(which was not certified by peer review) is the author/funder, who has granted medRxiv a license to display the preprint in perpetuity.

It is made available under a CC-BY-ND 4.0 International license .

\section{Discussion}

In a rural setting in Lao PDR with low documented COVID-19 transmission and high dependence on tourism, we found prevalent loss of income and increased difficulty in meeting household food needs following the start of the COVID-19 pandemic and a national border closure. In our household survey, we found that nearly four-fifths of the study population reported that it was harder to meet their family's food needs during the pandemic, with the most common reason being increases in food prices; indeed, families reported that the proportion of their household expenditure on food had doubled since baseline in 2017. At the same time, we found that over $85 \%$ of the study population reported losing income during the pandemic, with over half of respondents reported losing between $25-50 \%$ of their income. Respondents who reported losses in income and and/or reported greater challenges meeting their food needs had small, but significant declines in household food security, as measured by the food consumption score and coping strategies index. Nevertheless, the small differences in food security indicators suggests that people in this population may have been able largely able to protect their consumption without heavy reliance on negative coping strategies, despite some deterioration. Self-production of food via farming, hunting, fishing, or fathering is common in this population, accounting for $42 \%$ of food consumed. Our study found that individuals who derived a greater proportion of the food from self-produced means were more resilient to pandemic-associated shocks.

Our results support a limited, but growing, body of empirical data that suggests wide scale difficulty in meeting food needs and pervasive loss in income associated with the pandemic. In Kenya, surveys administered before and after the COVID-19 lockdown 
medRxiv preprint doi: https://doi.org/10.1101/2021.07.27.21261221; this version posted July 30, 2021. The copyright holder for this preprint (which was not certified by peer review) is the author/funder, who has granted medRxiv a license to display the preprint in perpetuity. It is made available under a CC-BY-ND 4.0 International license .

found that $52 \%$ of the population changed their dietary habits, most commonly via reductions in meat, dairy, and bread [30]. Nearly all (95\%) of respondents reported loss of income during the pandemic, with $88 \%$ finding that the resulting income was insufficient to meet food needs. Over one third also attributed changes in food consumption to lower food availability [30]. An interrupted time series analysis in Bangladesh found that median incomes fell from US\$212 to $\$ 59$ during a two-month stay at home order, while the proportion of families living on less than $\$ 1.90$ per day rose from $0.2 \%$ to $47.3 \%$ [31]. In this study, the proportion of households classified as moderately or severely food insecure rose from $5.6 \%$ and $2.7 \%$, respectively, to $36.5 \%$ and $15.3 \%$ [31]. Finally, in a Save the Children global survey, $85 \%$ of families living in Asia reported income loss, with a strong negative association between income loss and dietary diversity [21]. No study has yet to be published from Lao PDR, but an unpublished household survey in Phongsaly Province, another rural province, found that $46 \%$ of households reduced their expenditures, and $24 \%$ took out loans to buy food (personal communication).

Randomized control trials demonstrate that improved access to proper nutrition can improve WAZ and WHZ Z-scores [32-34]. We examined theoretical implications of a decrease in bodyweight on undernutrition prevalence, finding that a decrease in bodyweight of only $0.5-1 \%$ would be associated with a larger percentage point increase in wasting $(1.7-2.1$ percentage points $)$ and underweight $(0.8-2.3$ percentage points) in our study population. While LMICs have seen progress in reducing prevalence of wasting and underweight, yearly reductions are small. Analysis of DHS data collected between 1990 and 2012 from 36 LMICs found that, on average, 
medRxiv preprint doi: https://doi.org/10.1101/2021.07.27.21261221; this version posted July 30, 2021. The copyright holder for this preprint (which was not certified by peer review) is the author/funder, who has granted medRxiv a license to display the preprint in perpetuity. It is made available under a CC-BY-ND 4.0 International license .

the prevalence of wasting decreased by 0.07 percentage points per year [35], while in Lao PDR, the prevalence of underweight decreased by an average of 1.1 percentage points per year between 2012 and 2017 [14, 36]. This suggests that even small effects of COVID-19 on food security, and thus bodyweight, could undo years of progress. This echoes findings from a study conducted in India and is likely generalizable to many LMICs where there is a high prevalence of undernutrition [27]. At the same time, we did not observe a difference in the WAZ or WHZ scores between children whose household reported greater difficulty meeting food needs and those who did not, nor did we see a difference in child dietary diversity score between these groups in multivariate analyses. This may suggest that households in our study population prioritized maternal and child consumption patterns even as families struggled to meet food needs. All villages in the study population have been receiving interventions focused on sustainable behavioral change for maternal and child nutrition, so individuals in the population may have been more likely to prioritize the nutrition of these vulnerable populations.

Our study suggests possible interventions that might mitigate the effect of the pandemic on food security. We found that households who were more likely to experience no change in meeting food needs during the pandemic derived a greater proportion of their food needs through homegrown methods (as opposed to purchasing foods) as compared to households who found it more difficult to meet their food needs. Reducing reliance on food supply from other places or countries is recognized by others to be a means of reducing the impact of the COVID-19 pandemic on food insecurity. Farm-system-for-nutrition approaches have been suggested as one solution, in which location-specific farm systems that integrate arable farming, horticulture, backyard 
medRxiv preprint doi: https://doi.org/10.1101/2021.07.27.21261221; this version posted July 30, 2021. The copyright holder for this preprint

farming, and animal farming [37]. The FAO advocate for improving the resilience of local food systems by facilitating access to locally produced food, shortening the supply chain by promoting direct purchase from local producers, and promoting urban or backyard gardens that also offer financial and environmental co-benefits [38].

Our study also identified that loss of income and higher food prices are among the most important reason households are less able to meet their food needs. As such, social safety net programs may be particularly suited to addressing the challenge of food insecurity $[7,39,40]$. A randomized control trial in Colombia in March 2020, at the start of a national quarantine, found that $90 \%$ of families randomized to an arm that received cash transfers of $\$ 19$ every 5-9 weeks spent the cash on food, which helped to offset the effects of the pandemic on food insecurity in the treatment arm [41]. Other randomized control trials demonstrate reductions of severe food insecurity among those who received a cash transfer or a direct food transfer by nearly $25 \%[42,43]$. Systematic review and meta-analysis of 74 studies found that children from households who received cash transfers had reduced stunting by $2.5 \%$ and improved consumption of animal foods by $4.5 \%$ [44].

This study has limitations. First, the results of this survey may not be generalizable to other countries, particularly those with higher COVID-19 incidence and greater restrictions on within-country movement. At the time of the survey (November 2020), fewer than 50 cases had been reported in Lao PDR, and health systems were not experiencing the same overwhelming of capacity as in many other countries [45]. Additionally, while initial control measures limited local movement, these restrictions were largely relaxed by May 2020, seven months prior to the survey, with the main 
medRxiv preprint doi: https://doi.org/10.1101/2021.07.27.21261221; this version posted July 30, 2021. The copyright holder for this preprint

intervention remaining being strict border closure. We expect, therefore, that compared to other LMICs, the effects of food security and access to health care found in this study may be smaller than would be seen in other countries. At the same time, however, the effects of the pandemic on food security and income and expenditures may be seen more strongly in Luang Prabang as compared to other provinces within Lao PDR. As the province is home to the UNESCO World Heritage City of Luang Prabang, Luang Prabang province receives a greater proportion of its income from tourism as compared to other provinces [20]. Indeed, our survey found a greater proportion of household reduced expenditures (64\%) compared to another, unpublished, survey in a different rural province, where $46 \%$ of households reduced expenditures (personal communication). As mentioned, households in the study population had been receiving educational messaging regarding the importance of maternal and child malnutrition, so may have prioritized meeting the needs of mothers and children even as their struggled to meet the families' food needs. Thus it is possible that other areas may have seen more dramatic declines in maternal and child nutrition. Moreover, the results of the survey may not be generalizable to larger, more urban areas. Finally, the relationships with FCS may not be generalizable to other areas with different dietary patterns. The mean FCS in our study was 60.9 , well above the generic cut off of $\geq 35$ for an acceptable score. While diversity of foods consumed was low, consumption of staples and meat/fish/insects was high, and these food groups are given large weights in calculating the weighted mean.

Another limitation of our study relates to recall bias. Because control measures were first implemented in March 2020, and we implemented this survey in November 
medRxiv preprint doi: https://doi.org/10.1101/2021.07.27.21261221; this version posted July 30, 2021. The copyright holder for this preprint

(which was not certified by peer review) is the author/funder, who has granted medRxiv a license to display the preprint in perpetuity.

It is made available under a CC-BY-ND 4.0 International license .

2020, there could be substantial recall bias, as participants are asked to compare ability to meet food needs, ability to access health care, and income and expenditures to a time period that extended 8 months prior up until the current time. The ideal observational research design would be to compare our estimates of food security and malnutrition to repeated estimates taken longitudinally, leading up to just prior to the pandemic. While we lack data from just before the pandemic, we have data from household surveys in the region collected in 2017. Estimates of food insecurity and the prevalence of children underweight and wasted from 2020 are higher than estimates from 2017, while estimates of dietary diversity from 2020 are lower than estimates from 2017. However, because changes in indicators between 2017 and 2020 cannot be attributed to the effects of the pandemic alone, we do not emphasize 2017 data here.

\section{Conclusion}

Lao PDR's early efforts to control the spread of COVID-19 have been successful, with fewer documented cases to date relative to neighboring countries. Nevertheless, the effect of the pandemic on food security in livelihoods in LMICs may be severe, and the second wave of cases, and associated lockdown measures, in April 2021 demonstrates that the threat of continued food security remains present. Increasing selfsufficiency through local food production, and/or supporting incomes via social safety nets such as cash transfer programs, may mitigate some of these effects. As control measures to curb the transmission of COVID-19 continue, and as outbreaks occur intermittently with concomitant restrictions on movement, further study may be useful to understand what coping strategies people are using so that government and agencies can support the resilience of households in the long term. 
medRxiv preprint doi: https://doi.org/10.1101/2021.07.27.21261221; this version posted July 30, 2021. The copyright holder for this preprint (which was not certified by peer review) is the author/funder, who has granted medRxiv a license to display the preprint in perpetuity.

It is made available under a CC-BY-ND 4.0 International license .

\section{References}

1. Akseer N, Kandru G, Keats EC, Bhutta ZA. COVID-19 pandemic and mitigation strategies: implications for maternal and child health and nutrition. The American Journal of Clinical Nutrition. 2020;112(2):251-6.

2. Headey D, Heidkamp R, Osendarp S, Ruel M, Scott N, Black R, et al. Impacts of COVID-19 on childhood malnutrition and nutrition-related mortality. The Lancet. 2020;396(10250):519-21.

3. The Lancet Global H. Food insecurity will be the sting in the tail of COVID-19. The Lancet Global Health. 2020;8(6):e737.

4. United Nations Sustainable Development Group. Policy Brief: The impact of COVID-19 on food security and nutrition. 2020.

5. Aday S, Aday MS. Impact of COVID-19 on the food supply chain. Food Quality and Safety. 2020;4(4):167-80.

6 . Torero M. Without food, there can be no exit from the pandemic. Nature. 2020;580(7805):588-9.

7. Laborde D, Martin W, Vos R. Poverty and food insecurity could grow dramatically as COVID-19 spreads: International Food Policy Research Institute; 2020 [Available from:

https://www.ifpri.org/blog/poverty-and-food-insecurity-could-grow-dramatically-covid-19-spreads.

8. COVID-19 will double number of people facing food crises unless swift action is taken [press release]. 2020.

9. UNICEF. Tracking the situation of children during COVID-19 2020 [Available from: https://data.unicef.org/resources/rapid-situation-tracking-covid-19-socioeconomic-impacts-datavizl.

10. Black RE, Allen LH, Bhutta ZA, Caulfield LE, de Onis M, Ezzati M, et al. Maternal and child undernutrition: global and regional exposures and health consequences. Lancet. 2008;371(9608):243-60.

11. Black RE, Victora CG, Walker SP, Bhutta ZA, Christian P, de Onis M, et al. Maternal and child undernutrition and overweight in low-income and middle-income countries. Lancet. 2013;382(9890):427-51.

12. Roberton T, Carter ED, Chou VB, Stegmuller AR, Jackson BD, Tam Y, et al. Early estimates of the indirect effects of the COVID-19 pandemic on maternal and child mortality in low-income and middle-income countries: a modelling study. The Lancet Global Health. 2020;8(7):e901-e8.

13. Fore HH, Dongyu Q, Beasley DM, Ghebreyesus TA. Child malnutrition and COVID-19: the time to act is now. The Lancet. 2020;396(10250):517-8.

14. Lao Statistics Bureau. Lao Social Indicator Survey II 2017, Survey findings report. Vientiane, Lao PDR: Lao Statistics Bureau and UNICEF; 2018.

15. World Health Organization. Ministry of Health and WHO respond to first case of COVID19 in Laos Vientiane: WHO; 2020 [Available from: https://www.who.int/laos/news/detail/24-032020-ministry-of-health-and-who-respond-to-first-case-of-covid-19-in-laos.

16. United Nations Sustainable Development Group. UN Lao PDR Socio-Economic Response Framework to COVID-19 Vientiene: UNSDG; 2020 [Available from: https://reliefweb.int/report/lao-peoples-democratic-republic/un-lao-pdr-socio-economicresponse-framework-covid-19.

17. Dong E, Du H, Gardner L. An interactive web-based dashboard to track COVID-19 in real time. The Lancet Infectious diseases. 2020.

18. Food and Agriculture Organization. FAO Big Data tool on Covid-19 impact on food value chains 2020 [Available from: http://datalab.review.fao.org/datalab/website/covid19.

19. Sengpaseuth P. Govt officials urged to expedite aid to the unemployed. Vientiane Times. 2020. 
medRxiv preprint doi: https://doi.org/10.1101/2021.07.27.21261221; this version posted July 30, 2021. The copyright holder for this preprint (which was not certified by peer review) is the author/funder, who has granted medRxiv a license to display the preprint in perpetuity. It is made available under a CC-BY-ND 4.0 International license .

20. Yamano T, Pradhananga M, Schipani S, Samson JN, Quiao L, Leuangkhamsing S, et al. The Impact of COVID-19 on Tourism Enterprises in the Lao People's Democratic Republic: An Initial Assessment. Vientiane: Asian Development Bank; 2020.

21. Burgess M, Sulaiman M, Arlini SM, Qaiser MH, Thiyagarajah S, Dulieu N, et al. The Hidden Impact of Covid-19 on Children: A Global Research Series: Save the Children,; 2020 [Available from: https://resourcecentre.savethechildren.net/library/hidden-impact-covid-19children-global-research-series.

22. World Food Programme. Food consumption analysis: Calculation and use of the food consumption score in food security analysis. Rome, Italy: WFP; 2008.

23. Maxwell D, Caldwell R. The Coping Strategies Index: Field Methods Manuel. Rome: World Food Programme; 2008.

24. Maxwell D, Vaitla B, Coates J. How do indicators of household food insecurity measure up? An empirical comparison from Ethiopia. Food Policy. 2014;47:107-16.

25. Food For Peace. FFP Standard Indicator Handbook. Washington DC: USAID; 2011.

26. Bloem M. The 2006 WHO child growth standards. BMJ : British Medical Journal. 2007;334(7596):705-6.

27. Rajpal S, Joe W, Subramanian S. Living on the edge? Sensitivity of child undernutrition prevalence to bodyweight shocks in the context of the 2020 national lockdown strategy in India. Journal of Global Health Science. 2020;2.

28. R Core Team. R: A language and environment for statistical computing. Vienna, Austria: R Foundation for Statistical Computing; 2015.

29. Lumley T. survey: analysis of complex survey samples. 3.30 ed. R Package2014.

30. Shupler M, Mwitari J, Gohole A, Anderson de Cuevas R, Puzzolo E, Čukić I, et al.

COVID-19 impacts on household energy \& food security in a Kenyan informal settlement: The need for integrated approaches to the SDGs. Renewable and Sustainable Energy Reviews. 2021;144:111018.

31. Hamadani JD, Hasan MI, Baldi AJ, Hossain SJ, Shiraji S, Bhuiyan MSA, et al. Immediate impact of stay-at-home orders to control COVID-19 transmission on socioeconomic conditions, food insecurity, mental health, and intimate partner violence in Bangladeshi women and their families: an interrupted time series. The Lancet Global Health. 2020;8(11):e1380-e9. 32. Null C, Stewart CP, Pickering AJ, Dentz HN, Arnold BF, Arnold CD, et al. Effects of water quality, sanitation, handwashing, and nutritional interventions on diarrhoea and child growth in rural Kenya: a cluster-randomised controlled trial. The Lancet Global Health. 2018;6(3):e316-e29.

33. Luby SP, Rahman M, Arnold BF, Unicomb L, Ashraf S, Winch PJ, et al. Effects of water quality, sanitation, handwashing, and nutritional interventions on diarrhoea and child growth in rural Bangladesh: a cluster randomised controlled trial. The Lancet Global Health. 2018;6(3):e302-e15.

34. Humphrey JH, Mbuya MNN, Ntozini R, Moulton LH, Stoltzfus RJ, Tavengwa NV, et al. Independent and combined effects of improved water, sanitation, and hygiene, and improved complementary feeding, on child stunting and anaemia in rural Zimbabwe: a cluster-randomised trial. The Lancet Global Health. 2019;7(1):e132-e47.

35. Tzioumis E, Kay MC, Bentley ME, Adair LS. Prevalence and trends in the childhood dual burden of malnutrition in low- and middle-income countries, 1990-2012. Public health nutrition. 2016;19(8):1375-88.

36. Ministry of Health and Lao Statistics Bureau. Lao Social Indicator Survey. Vientiane, Lao PDR; 2012.

37. Bhavani RV, Gopinath R. The COVID19 pandemic crisis and the relevance of a farmsystem-for-nutrition approach. Food security. 2020:1-4.

38. FAO. COVID-19 and the role of local food production in building more resilient local food systems. Rome; 2020. 
medRxiv preprint doi: https://doi.org/10.1101/2021.07.27.21261221; this version posted July 30, 2021. The copyright holder for this preprint (which was not certified by peer review) is the author/funder, who has granted medRxiv a license to display the preprint in perpetuity.

It is made available under a CC-BY-ND 4.0 International license .

39. Amjath-Babu T, Krupnik TJ, Thilsted SH, McDonald AJ. Key indicators for monitoring food system disruptions caused by the COVID-19 pandemic: Insights from Bangladesh towards effective response. Food security. 2020;12(4):761-8.

40. Gilligan D. Social safety nets are crucial to the COVID-19 response: Some lessons to boost their effectiveness. IFPRI book chapters. 2020:102-5.

41. Londoño-Vélez J, Querubin P, editors. The Impact of Emergency Cash Assistance in a Pandemic: Experimental Evidence from Colombia. 113th Annual Conference on Taxation; 2020: NTA.

42. Fahey CA, Njau PF, Dow WH, Kapologwe NA, McCoy SI. Effects of short-term cash and food incentives on food insecurity and nutrition among HIV-infected adults in Tanzania. AIDS (London, England). 2019;33(3):515-24.

43. Fenn B, Bulti AT, Nduna T, Duffield A, Watson F. An evaluation of an operations research project to reduce childhood stunting in a food-insecure area in Ethiopia. Public health nutrition. 2012;15(9):1746-54.

44. Manley J, Balarajan Y, Malm S, Harman L, Owens J, Murthy S, et al. Cash transfers and child nutritional outcomes: a systematic review and meta-analysis. BMJ global health. 2020;5(12).

45. Walker PGT, Whittaker C, Watson OJ, Baguelin M, Winskill P, Hamlet A, et al. The impact of COVID-19 and strategies for mitigation and suppression in low- and middle-income countries. Science. 2020;369(6502):413-22. 


\section{Supplemental Info: Survey tool}

\section{Endline Interview Questionnaire - 2020 Health and Nutrition Assessment}

\begin{tabular}{|c|}
\hline Introductory Statement to the Interview \\
\hline $\begin{array}{l}\text { Good Morning/Good Afternoon. } \\
\text { My name is } \\
\text { program. We are conducting a survey on the health and nutritional status of women and } \\
\text { children. You have been selected by chance from the list of families with children under the } \\
\text { age of five. Is this correct? The purpose of this interview is to obtain information about the } \\
\text { health and nutrition status of you and your child. We are interested in interviewing mothers of } \\
\text { children aged five or less. Are you the mother of the child? (If no), Is the mother of the child } \\
\text { at home? (If yes, wait until she arrives, and re-explain purpose). Could you please spare } \\
\text { some time (around } 45 \text { minutes) for the interview? The information you give will be } \\
\text { confidential and will only be used to prepare a report of general findings - but will not include } \\
\text { any names. You will not get any additional entitlements because of the interview. At any time } \\
\text { during the survey, you are free to stop the survey, or choose not answer any question. If you } \\
\text { are willing to participate in this survey, please indicate your oral consent by saying "yes" or } \\
\text { "no". }\end{array}$ \\
\hline May I start now? \\
\hline $\begin{array}{c}\square \text { Yes, permission is given } \Rightarrow \text { Go to } 101 \text { to begin the interview. } \\
\square \text { No, permission is not given } \Rightarrow \text { Tell this result to your supervisor and move to the next } \\
\text { household. }\end{array}$ \\
\hline $\begin{array}{l}\text { Enumerators- If the respondent is not willing, do not ask any of the questions and move to } \\
\text { the next household. If the household contains children under the age of } 5 \text {, but the mother is } \\
\text { not present, ask when it is a good time to return, and return at a later time. We only want to } \\
\text { interview mothers of children under the age of } 5 .\end{array}$ \\
\hline
\end{tabular}


medRxiv preprint doi: https://doi.org/10.1101/2021.07.27.21261221; this version posted July 30, 2021. The copyright holder for this preprint (which was not certified by peer review) is the author/funder, who has granted medRxiv a license to display the preprint in perpetuity.

\begin{tabular}{|l|l|l|l|l|}
\hline \multicolumn{3}{|l|}{ General Information } & Name \\
\hline No. & Item & \multicolumn{2}{l|}{} \\
\hline 101 & District & \multicolumn{3}{l|}{} \\
\hline 102 & Village & DD & MM & YYYY \\
\cline { 3 - 5 } 103 & \multirow{2}{*}{ Date of interview } & -- & -- & 2016 \\
\hline 104 & Interviewer's Name/Number & & \multicolumn{2}{l}{} \\
\hline
\end{tabular}

\section{Household Demographic Information}

First, we would like to ask some questions about yourself and the people who live in this household.

\begin{tabular}{|c|c|c|c|}
\hline No. & Question & Response & Notes \\
\hline 201 & How old are you? & Age (in completed years): & \\
\hline 202 & $\begin{array}{l}\text { To what ethnic group does } \\
\text { the head of this household } \\
\text { belong? }\end{array}$ & 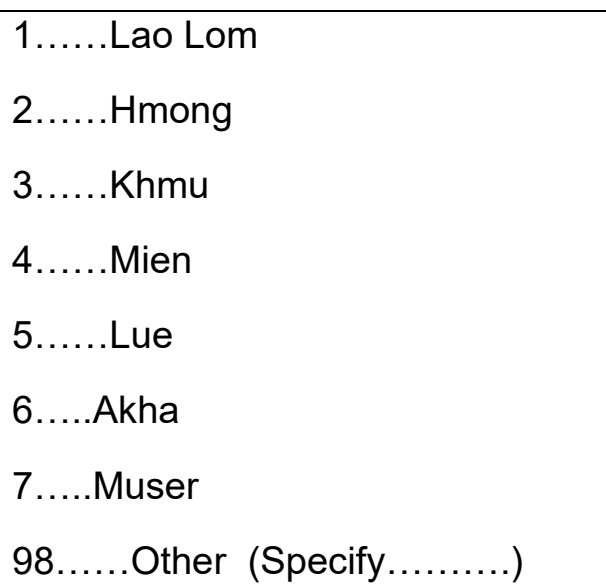 & \\
\hline 203 & What is your marital status? & $\begin{array}{l}\text { 1.......Married (monogamous) } \\
2 \ldots . . . . \text { Married (polygamous) } \\
\text { 3.......Not married, but living with a } \\
\text { man } \\
\text { 4......Single } \\
5 \ldots \ldots . \text { Divorced or separated } \\
6 \ldots . . . \text {. Widowed }\end{array}$ & \\
\hline
\end{tabular}


medRxiv preprint doi: https://doi.org/10.1101/2021.07.27.21261221; this version posted July 30, 2021. The copyright holder for this preprint (which was not certified by peer review) is the author/funder, who has granted medRxiv a license to display the preprint in perpetuity.

It is made available under a CC-BY-ND 4.0 International license .

\begin{tabular}{|c|c|c|c|}
\hline 204 & $\begin{array}{l}\text { What is your relationship to } \\
\text { the head of the household } \\
(\mathrm{HHH}) \text { ? }\end{array}$ & 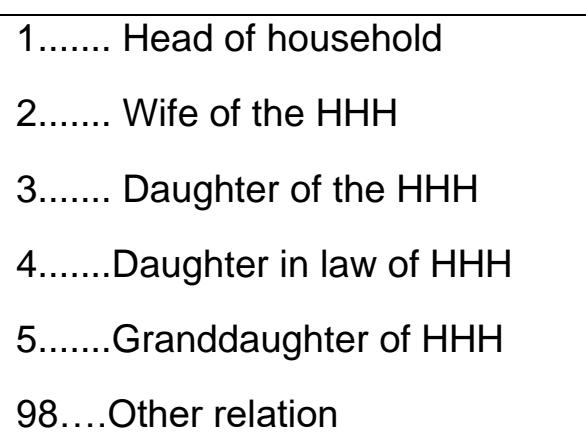 & $\begin{array}{l}1 \rightarrow 206 \\
2 \rightarrow 206\end{array}$ \\
\hline 205 & $\begin{array}{l}\text { Is the head of the household } \\
\text { male or female? }\end{array}$ & $\begin{array}{l}\text { 0.......Female } \\
\text { 1........Male }\end{array}$ & $\begin{array}{l}\text { if } 204 \neq 1 \\
\text { or } 2\end{array}$ \\
\hline 206 & $\begin{array}{l}\text { Have you ever attended } \\
\text { school? }\end{array}$ & $\begin{array}{l}1 \ldots \ldots . \text { Yes } \\
0 \ldots \ldots \text {.... }\end{array}$ & $0 \rightarrow 208$ \\
\hline 207 & $\begin{array}{l}\text { What is the highest level of } \\
\text { school you completed? }\end{array}$ & $\begin{array}{l}\text { 1.......Preschool } \\
2 \ldots . . . . \text { Primary } \\
\text { 3.......Lower Secondary } \\
4 \ldots . . . \text { Upper secondary } \\
5 \ldots . . . \text { Post-secondary vocational, } \\
\text { tertiary/ diploma } \\
6 \ldots . . . \text {.Higher }\end{array}$ & if $206=1$ \\
\hline 208 & $\begin{array}{l}\text { Did the head of the } \\
\text { household attend school? }\end{array}$ & $\begin{array}{l}1 \ldots . . . \text { Yes } \\
0 \ldots \ldots \text {..... } \\
\text { 99....Don't know }\end{array}$ & $\begin{array}{l}\text { if } 204 \neq 1 \\
1 \rightarrow 209 \\
0 \rightarrow 210\end{array}$ \\
\hline 209 & $\begin{array}{l}\text { What is the highest level of } \\
\text { school completed by the } \\
\text { head of the household? }\end{array}$ & $\begin{array}{l}\text { 1.......Preschool } \\
2 . . . . . \text { Primary } \\
\text { 3.......Lower Secondary } \\
\text { 4.......Upper secondary } \\
5 \ldots . . . \text { Post-secondary vocational, } \\
\text { tertiary/ diploma } \\
\text { 6.......Higher } \\
\text { 99...Don't know }\end{array}$ & if $208=1$ \\
\hline 210 & $\begin{array}{l}\text { How many household } \\
\text { members are aged } 15 \text { years } \\
\text { or more? }\end{array}$ & - & \\
\hline
\end{tabular}


medRxiv preprint doi: https://doi.org/10.1101/2021.07.27.21261221; this version posted July 30, 2021. The copyright holder for this preprint (which was not certified by peer review) is the author/funder, who has granted medRxiv a license to display the preprint in perpetuity.

\begin{tabular}{|c|c|c|c|}
\hline & $\begin{array}{l}\text { Prompt to include self in this } \\
\text { count }\end{array}$ & & \\
\hline 211 & $\begin{array}{l}\text { How many household } \\
\text { members are below } 15 \text { years } \\
\text { of age? }\end{array}$ & - & \\
\hline 212 & $\begin{array}{l}\text { How many household } \\
\text { members are below } 5 \text { years } \\
\text { of age? }\end{array}$ & - & $\begin{array}{l}\text { Check: } \\
212 \leq 211\end{array}$ \\
\hline 213 & $\begin{array}{l}\text { How many members are in } \\
\text { your own family? }\end{array}$ & - & \\
\hline
\end{tabular}

\section{Dietary Intake}

Now we would like to ask some questions about the diet of yourself and one of your children.

Enumerators, if there are more than one children under the age of five, randomly select one child. Ask the name of the child, and use that name for the rest of the interview.

\begin{tabular}{|c|c|c|c|}
\hline No. & Question & Response & Notes \\
\hline 400 & $\begin{array}{l}\text { When was this child born? } \\
\text { Probe: Using MCH book, house } \\
\text { registration, other official document }\end{array}$ & --- & \\
\hline 401 & $\begin{array}{l}\text { How many months old is this child? } \\
\text { Probe: Using important holidays, } \\
\text { dates, etc. }\end{array}$ & ___ months & 0-59 only! \\
\hline 402 & $\begin{array}{l}\text { Is the child selected (Child's name) } \\
\text { your youngest child? } \\
\text { Probe: the last child of alive } \\
\text { children? }\end{array}$ & $\begin{array}{l}1 \ldots . . . \text { Yes } \\
0 \ldots \ldots . \text { No }\end{array}$ & \\
\hline 403 & $\begin{array}{l}\text { Yesterday during the day or night, } \\
\text { was your diet a typical diet? } \\
\text { Probe: She had special ceremonies } \\
\text { or illnesses that led her to have } \\
\text { less or much more than her typical } \\
\text { eating.? }\end{array}$ & $\begin{array}{l}1 \ldots \ldots . \text { Yes } \\
2 \ldots \ldots . \text { No. I ate more. } \\
3 \ldots \ldots . \text { No. I ate less } \\
99 \ldots \ldots \text {.... not know }\end{array}$ & \\
\hline 404 & $\begin{array}{l}\text { Yesterday during the day or night, } \\
\text { did you eat more or less or same } \\
\text { amount of food compared to your } \\
\text { eating before this pregnancy? }\end{array}$ & $\begin{array}{l}1 \ldots . . . \text { Increased amount } \\
2 \ldots \ldots \text {. Same amount } \\
3 \ldots \ldots \text {. Decreased amount } \\
99 \ldots . . \text {.Do not know }\end{array}$ & $\begin{array}{l}\text { if } 226=1 \\
\text { (currently } \\
\text { pregnant) }\end{array}$ \\
\hline
\end{tabular}


medRxiv preprint doi: https://doi.org/10.1101/2021.07.27.21261221; this version posted July 30, 2021. The copyright holder for this preprint (which was not certified by peer review) is the author/funder, who has granted medRxiv a license to display the preprint in perpetuity.

\begin{tabular}{|c|c|c|c|}
\hline 405 & $\begin{array}{l}\text { Yesterday during the day or night, } \\
\text { did you eat more or less or same } \\
\text { amount of animal source foods } \\
\text { compared to your eating before this } \\
\text { pregnancy? } \\
\text { Probe: Using examples of animal } \\
\text { food or product in their general } \\
\text { contexts and comparing with her } \\
\text { usual eating style }\end{array}$ & $\begin{array}{l}\text { 1...... Increased amount } \\
2 \ldots . . \text { Same amount } \\
3 \ldots . . \text {. Decreased amount } \\
99 . \ldots \text {...Do not know }\end{array}$ & $\begin{array}{l}\text { if } 226=1 \\
\text { (currently } \\
\text { pregnant) }\end{array}$ \\
\hline 406 & \multicolumn{2}{|c|}{$\begin{array}{l}\text { I would like to ask you about foods that you may have had } \\
\text { yesterday during the day or night. I am interested to know } \\
\text { whether you had the item even if combined with other foods. } \\
\text { Please include foods consumed outside of your home. } \\
\text { YESTERDAY DURING THE DAY OR NIGHT, DID YOU } \\
\text { DRINK/EAT (FOOD GROUP ITEMS)? } \\
\text { Questions and filters (Circle the corresponding code and you can } \\
\text { underline more than one answer) } \\
\text { Always start with: 'YESTERDAY DID YOU EAT....' }\end{array}$} & \\
\hline $406 a$ & $\begin{array}{l}\text { Any offal items (excluding } \\
\text { intestines)? } \\
\text { Probe: such as liver, brain, lung, } \\
\text { heart, gizzard, kidney, of any } \\
\text { animal }\end{array}$ & $\begin{array}{l}1 \ldots . . . \text { Yes } \\
0 \ldots \ldots \text {.... } \\
99 \ldots . . \text {.Do not know }\end{array}$ & \\
\hline 406b & The intestine of any animal? & $\begin{array}{l}1 \ldots . . . \text { Yes } \\
0 \ldots \ldots \text {.... } \\
99 \ldots . . . \text { Do not know }\end{array}$ & \\
\hline 406c & $\begin{array}{l}\text { Any kind of meat? } \\
\text { Probe: such as any meat, such as } \\
\text { beef (fresh or dry), buffalo, pork, } \\
\text { goat, chicken, goose, duck, } \\
\text { sausage, blood sausage, sour } \\
\text { sausage }\end{array}$ & $\begin{array}{l}1 \ldots \ldots \text { Yes } \\
0 \ldots \ldots \text {..... } \\
99 \ldots . . . \text { Do not know }\end{array}$ & \\
\hline 406d & $\begin{array}{l}\text { Any kind of eggs? } \\
\text { Probe: 'such as?' eggs from } \\
\text { chicken, duck, turtle or other } \\
\text { animals }\end{array}$ & $\begin{array}{l}1 \ldots . . \text { Yes } \\
0 \ldots \ldots \text {.... } \\
99 \ldots \ldots \text {..... no not know }\end{array}$ & \\
\hline $406 \mathrm{e}$ & $\begin{array}{l}\text { Any kind of fish or aquatic animals? } \\
\text { Probe: 'such as?' fresh, fermented } \\
\text { or dried fish, swamp eel, squid, }\end{array}$ & $\begin{array}{l}1 \ldots . . . \text { Yes } \\
0 \ldots \ldots \text {.... } \\
99 \ldots \ldots \text {..... no not know }\end{array}$ & \\
\hline
\end{tabular}


medRxiv preprint doi: https://doi.org/10.1101/2021.07.27.21261221; this version posted July 30, 2021. The copyright holder for this preprint (which was not certified by peer review) is the author/funder, who has granted medRxiv a license to display the preprint in perpetuity.

It is made available under a CC-BY-ND 4.0 International license .

\begin{tabular}{|c|c|c|}
\hline & $\begin{array}{l}\text { shrimp (fresh or dry), crab, } \\
\text { granulated ark, clam, snail, frog, } \\
\text { water insects }\end{array}$ & \\
\hline $406 f$ & $\begin{array}{l}\text { Any kind of wild animals? } \\
\text { Probe: 'such as?' lizard, rat, rabbit, } \\
\text { wild bird, small birds }\end{array}$ & $\begin{array}{l}1 \ldots . . \text { Yes } \\
0 \ldots . . . \text {.No } \\
99 \ldots . . . \text { Do not know }\end{array}$ \\
\hline $406 g$ & $\begin{array}{l}\text { Any kind of insects or grubs? } \\
\text { Probe: 'such as?' silk worm pupa, } \\
\text { cricket, weaver ant, ant egg, etc. }\end{array}$ & $\begin{array}{l}1 \ldots . . \text { Yes } \\
0 \ldots \ldots \text {.... } \\
99 \ldots . . . \text { Do not know }\end{array}$ \\
\hline 406h & $\begin{array}{l}\text { Any kind of dairy products (not } \\
\text { including coffee creamer)? } \\
\text { Probe: 'such as?' cheese (butter), } \\
\text { yogurt, or other milk products }\end{array}$ & $\begin{array}{l}1 \ldots . . . \text { Yes } \\
0 \ldots . . . \text { No } \\
99 \ldots . . . \text { Do not know }\end{array}$ \\
\hline $406 i$ & $\begin{array}{l}\text { Other foods that came from an } \\
\text { animal. Example: pork skin }\end{array}$ & $\begin{array}{l}1 \text { 1...... Yes } \\
0 \ldots \ldots \text {.... } \\
99 \ldots . . . \text { Do not know }\end{array}$ \\
\hline 406j & $\begin{array}{l}\text { Sticky rice (refined or unrefined), } \\
\text { roasted rice, rice, pre-chewed rice, } \\
\text { rice noodles, maize, noodles, thick } \\
\text { porridge, or other foods made from } \\
\text { grains? }\end{array}$ & $\begin{array}{l}1 \ldots . . \text { Yes } \\
0 \ldots \ldots \text {.... } \\
99 \ldots . . . \text { Do not know }\end{array}$ \\
\hline 406k & $\begin{array}{l}\text { White or purple coloured foods } \\
\text { from roots such as white yams, } \\
\text { purple yams, yam bean, cassava, } \\
\text { white radish, white potato, or any } \\
\text { other white or purple colored foods } \\
\text { from roots. }\end{array}$ & $\begin{array}{l}1 \ldots \ldots \text { Yes } \\
0 \ldots \ldots \text {.... } \\
99 \ldots \ldots \text {..... }\end{array}$ \\
\hline 406I & Pulses/lentils/tofu/bean curd & $\begin{array}{l}1 \ldots . . . \text { Yes } \\
0 \ldots \ldots \text {.... } \\
99 \ldots \ldots \text {..... no not know }\end{array}$ \\
\hline 406m & $\begin{array}{l}\text { Nuts or seeds (e.g. Sesame seeds, } \\
\text { mung bean, ground bean, sun } \\
\text { flower seed, cashew nuts etc.) }\end{array}$ & $\begin{array}{l}1 \ldots . . \text { Yes } \\
0 \ldots \ldots \text {.... } \\
99 \ldots . . \text { Do not know }\end{array}$ \\
\hline $406 n$ & $\begin{array}{l}\text { Any dark green leafy vegetables } \\
\text { such as pak choi, swamp cabbage, } \\
\text { morning glory, sweet potato leaves, } \\
\text { Chinese kale }\end{array}$ & $\begin{array}{l}1 \ldots . . \text { Yes } \\
0 \ldots \ldots \text {.... } \\
99 \ldots . . . \text { Do not know }\end{array}$ \\
\hline 4060 & $\begin{array}{l}\text { Ripe orange fleshed mangoes, ripe } \\
\text { orange fleshed papayas, pumpkin, } \\
\text { carrots, sweet potatoes that are } \\
\text { yellow or orange inside? }\end{array}$ & $\begin{array}{l}1 \ldots . . \text { Yes } \\
0 \ldots . . . \text {.No } \\
99 \ldots . . . \text { Do not know }\end{array}$ \\
\hline 406p & Other vegetables & $\begin{array}{l}1 \ldots . . \text { Yes } \\
0 \ldots \ldots \text {..... }\end{array}$ \\
\hline
\end{tabular}


medRxiv preprint doi: https://doi.org/10.1101/2021.07.27.21261221; this version posted July 30, 2021. The copyright holder for this preprint (which was not certified by peer review) is the author/funder, who has granted medRxiv a license to display the preprint in perpetuity.

\begin{tabular}{|c|c|c|c|}
\hline & & $99 . . . .$. Do not know & \\
\hline $406 q$ & Other fruit & $\begin{array}{l}1 \ldots . . . \text { Yes } \\
0 \ldots \ldots \text {.... } \\
99 \ldots . . \text { Do not know }\end{array}$ & \\
\hline \multicolumn{4}{|c|}{ Now, I would like to ask about feeding practices for your child selected. } \\
\hline 407 & $\begin{array}{l}\text { Has (CHILD'S NAME) ever been } \\
\text { breastfed? }\end{array}$ & $\begin{array}{l}1 \ldots . . \text { Yes } \\
0 \ldots \ldots \text { No }\end{array}$ & $\begin{array}{l}\text { if } 401< \\
24 \\
0 \rightarrow 409\end{array}$ \\
\hline 408 & $\begin{array}{l}\text { Was (CHILD's NAME) breastfed } \\
\text { yesterday, either during the day or } \\
\text { the night? }\end{array}$ & $\begin{array}{l}1 \ldots . . . \text { Yes } \\
0 \ldots \ldots \text {.... } \\
99 \ldots . . \text { Do not know }\end{array}$ & $\begin{array}{l}\text { if } 401< \\
24 \& 407 \\
=1\end{array}$ \\
\hline 409 & $\begin{array}{l}\text { Did (NAME) drink anything from a } \\
\text { bottle with a nipple yesterday, } \\
\text { during the day or night? }\end{array}$ & $\begin{array}{l}1 \ldots . . \text { Yes } \\
0 \ldots \ldots \text {..... } \\
99 \ldots . . \text { Do not know }\end{array}$ & $\begin{array}{l}\text { if } 401< \\
24\end{array}$ \\
\hline 410 & $\begin{array}{l}\text { Did (NAME) drink or eat vitamin or } \\
\text { mineral supplements yesterday, } \\
\text { during the day or night? }\end{array}$ & $\begin{array}{l}1 \ldots . . \text { Yes } \\
0 \ldots . . . \text { No } \\
99 \ldots . \text { Do not know }\end{array}$ & $\begin{array}{l}\text { if } 401< \\
24\end{array}$ \\
\hline 411 & $\begin{array}{l}\text { How long after birth did you first put } \\
\text { (NAME) to the breast? } \\
\text { If immediately, record 00. If less } \\
\text { than } 24 \text { hours, record hours. If over } \\
24 \text { hours, record } 25 \text {. If unknown, } \\
\text { record } 99 \text {. }\end{array}$ & hours & $\begin{array}{l}\text { if } 401< \\
24 \& 407 \\
=1\end{array}$ \\
\hline 412 & $\begin{array}{l}\text { Did (CHILD'S NAME) have any } \\
\text { liquid other than breast milk, such } \\
\text { as canned, powdered or fresh } \\
\text { animal milk, infant formula, juice, } \\
\text { thin porridge, or clear soup (Nam } \\
\text { Keang) yesterday, during the day } \\
\text { or night? }\end{array}$ & $\begin{array}{l}1 \ldots . . . \text { Yes } \\
0 \ldots \ldots \text {.... } \\
99 \ldots . . . \text { Do not know }\end{array}$ & $\begin{array}{l}\text { if } 401< \\
24 \\
0 \rightarrow 413 \\
99 \rightarrow 413\end{array}$ \\
\hline $412 a$ & $\begin{array}{l}\text { How many times did (CHILD'S } \\
\text { NAME) receive milk other than } \\
\text { breastmilk, such as canned, } \\
\text { powdered or fresh animal milk, or } \\
\text { infant formula? }\end{array}$ & $\frac{\text { times }}{99 \ldots . . . \text { Do not know }}$ & $\begin{array}{l}\text { if } \\
401=6- \\
23 \& 412 \\
=1\end{array}$ \\
\hline 413 & $\begin{array}{l}\text { When do you think is the best time } \\
\text { to start breastfeeding a child after } \\
\text { giving birth? }\end{array}$ & $\begin{array}{l}\text { Enumerators: read off all } \\
\text { answer choices and circle } \\
\text { the best one } \\
1 \ldots . . . \text { Within the first hour } \\
\text { after giving birth } \\
2 \ldots . . . \text { Within the first six } \\
\text { hours after giving birth }\end{array}$ & \\
\hline
\end{tabular}


medRxiv preprint doi: https://doi.org/10.1101/2021.07.27.21261221; this version posted July 30, 2021. The copyright holder for this preprint (which was not certified by peer review) is the author/funder, who has granted medRxiv a license to display the preprint in perpetuity.

\begin{tabular}{|c|c|c|c|}
\hline & & $\begin{array}{l}3 \ldots \ldots . \text { Within the first twelve } \\
\text { hours after giving birth } \\
4 \ldots \ldots . \text { Within one day after } \\
\text { giving birth } \\
99 . \ldots . . \text { Do not know }\end{array}$ & \\
\hline 414 & \multicolumn{2}{|c|}{$\begin{array}{l}\text { I would like to ask you about foods that the selected child } \\
\text { (CHILD'S NAME) may have had yesterday during the day or } \\
\text { night. I am interested to know whether HE/SHE had the item even } \\
\text { combined with other foods. Please include foods consumed } \\
\text { outside of your home. } \\
\text { YESTERDAY DURING THE DAY OR NIGHT, DID THE } \\
\text { SELECTED CHILD (CHILD'S NAME) DRINK/EAT (FOOD } \\
\text { GROUP ITEMS)? } \\
\text { Always start with: 'YESTERDAY DID (NAME) EAT...' }\end{array}$} & if $401 \geq 6$ \\
\hline $414 a$ & $\begin{array}{l}\text { Commercially fortified baby food, e.g., } \\
\text { cerelac }\end{array}$ & $\begin{array}{l}1 \ldots . . \text { Yes } \\
0 \ldots \ldots \text {.... } \\
99 \ldots \ldots \text {.... no not know }\end{array}$ & \\
\hline 414b & $\begin{array}{l}\text { Sticky rice (white or brown), } \\
\text { roasted rice, rice, pre-chewed rice, } \\
\text { rice noodles, maize, noodles, } \\
\text { porridge, or other foods made from } \\
\text { grains? }\end{array}$ & $\begin{array}{l}1 \ldots . . \text { Yes } \\
0 \ldots \ldots \text {.... } \\
99 \ldots \ldots \text {..... no not know }\end{array}$ & \\
\hline $414 c$ & $\begin{array}{l}\text { Pumpkin, carrots or sweet potatoes } \\
\text { that are yellow or orange inside? }\end{array}$ & $\begin{array}{l}1 \ldots . . . \text { Yes } \\
0 \ldots . . . \text { No } \\
99 \ldots . . \text { Do not know }\end{array}$ & \\
\hline 414d & $\begin{array}{l}\text { White or purple coloured foods } \\
\text { from roots such as white yams, } \\
\text { purple yams, yam bean, cassava, } \\
\text { white radish, white potato, or any } \\
\text { other white or purple colored foods } \\
\text { from roots. }\end{array}$ & $\begin{array}{l}1 \ldots . . . \text { Yes } \\
0 \ldots . . . \text {.No } \\
99 \ldots . . . \text { Do not know }\end{array}$ & \\
\hline $414 \mathrm{e}$ & $\begin{array}{l}\text { Any dark green, leafy vegetables } \\
\text { such as pak choi, swamp cabbage, } \\
\text { morning glory, sweet potato leaves, } \\
\text { Chinese kale? }\end{array}$ & $\begin{array}{l}1 \text { 1......Yes } \\
0 \ldots \ldots \text {.... } \\
99 \ldots . . \text { Do not know }\end{array}$ & \\
\hline $414 f$ & $\begin{array}{l}\text { Ripe or orange-fleshed mangos, or } \\
\text { papayas }\end{array}$ & $\begin{array}{l}1 \ldots . . . \text { Yes } \\
0 \ldots . . . \text {.No } \\
99 . . . . \text {..Do not know }\end{array}$ & \\
\hline $414 \mathrm{~g}$ & Any other fruits or vegetables & $\begin{array}{l}1 \ldots . . . \text { Yes } \\
0 \ldots . . . \text { No } \\
99 \ldots . . . \text { Do not know }\end{array}$ & \\
\hline $414 h$ & $\begin{array}{l}\text { Liver, brain, lung, heat, gizzard, } \\
\text { kidney, intestine, or other organ of } \\
\text { any animal }\end{array}$ & $\begin{array}{l}1 \ldots . . \text { Yes } \\
0 \ldots . . . \text { No } \\
99 \ldots . . . \text { Do not know }\end{array}$ & \\
\hline
\end{tabular}




\begin{tabular}{|c|c|c|c|}
\hline $414 i$ & $\begin{array}{l}\text { Any meat, such as beef (fresh or } \\
\text { dry), buffalo, pork, lamb, goat, } \\
\text { chicken, goose, duck, sausage, } \\
\text { blood sausage, sour sausage }\end{array}$ & $\begin{array}{l}1 \ldots . . . \text { Yes } \\
0 \ldots \ldots \text {.... } \\
99 \ldots . . \text { Do not know }\end{array}$ & \\
\hline 414j & $\begin{array}{l}\text { Eggs from chicken, duck, turtle or } \\
\text { other animals }\end{array}$ & $\begin{array}{l}1 \ldots . . . \text { Yes } \\
0 \ldots \ldots \text {.... } \\
99 \ldots . . . \text { Do not know }\end{array}$ & \\
\hline 414k & $\begin{array}{l}\text { Fresh, fermented or dried fish, } \\
\text { swamp eel, squid, shrimp (fresh or } \\
\text { dry), shellfish, crab, granulate ark, } \\
\text { clam, snail }\end{array}$ & $\begin{array}{l}1 \ldots . . . \text { Yes } \\
0 \ldots \ldots \text {.... } \\
99 \ldots . . \text { Do not know }\end{array}$ & \\
\hline 414I & $\begin{array}{l}\text { Any wild animals such as lizard, frog, } \\
\text { rat, rabbit, wild bird, small bird }\end{array}$ & $\begin{array}{l}1 \ldots . . \text { Yes } \\
0 \ldots \ldots \text {.... } \\
99 \ldots . . \text { Do not know }\end{array}$ & \\
\hline $414 m$ & $\begin{array}{l}\text { Insects or grubs such as silk worm } \\
\text { pupa, cricket, weaver ant, any } \\
\text { insect eggs, water insects }\end{array}$ & $\begin{array}{l}1 \ldots . . \text { Yes } \\
0 \ldots \ldots \text {.... } \\
99 \ldots . . \text { Do not know }\end{array}$ & \\
\hline $414 n$ & $\begin{array}{l}\text { Any foods made from beans, } \\
\text { Leucanea (bean), common pea, } \\
\text { lentils, or nuts, including tofu? }\end{array}$ & $\begin{array}{l}1 \ldots . . . \text { Yes } \\
0 \ldots \ldots \text {.... } \\
99 \ldots . . \text { Do not know }\end{array}$ & \\
\hline 4140 & $\begin{array}{l}\text { Cheese, yogurt, or other food made } \\
\text { from milk? }\end{array}$ & $\begin{array}{l}1 \ldots . . \text { Yes } \\
0 \ldots . . . \text { No } \\
99 \ldots . . \text { Do not know }\end{array}$ & \\
\hline $414 p$ & $\begin{array}{l}\text { Any oil, pork fat, or butter or foods } \\
\text { made with any of these }\end{array}$ & $\begin{array}{l}1 \ldots . . \text { Yes } \\
0 \ldots \ldots \text {.... } \\
99 \ldots . . \text { Do not know }\end{array}$ & \\
\hline $414 q$ & $\begin{array}{l}\text { Any packaged foods such as } \\
\text { packaged noodles, chocolates, } \\
\text { sweets, candies, pastries, cakes, or } \\
\text { biscuits }\end{array}$ & $\begin{array}{l}1 \ldots . . \text { Yes } \\
0 \ldots \ldots \text {.... } \\
99 \ldots . . \text { Do not know }\end{array}$ & \\
\hline 415 & $\begin{array}{l}\text { How meals (solid or semi-solid } \\
\text { food) did (CHILD'S NAME) eat } \\
\text { yesterday? } \\
\text { Enter } 99 \text { if unknown }\end{array}$ & $\begin{array}{l}\text { times } \\
99 . . . . . \text { Do not know }\end{array}$ & if $401 \geq 6$ \\
\hline 416 & $\begin{array}{l}\text { Did (CHILD'S NAME) eat any solid, } \\
\text { semi-solid or soft foods (such as } \\
\text { porridge, rice, pre-chewed rice, } \\
\text { fruits, bread, meat, eggs, } \\
\text { vegetables) yesterday? }\end{array}$ & $\begin{array}{l}1 \ldots . . \text { Yes } \\
0 \ldots \ldots \text {.... } \\
99 \ldots . . \text { Do not know }\end{array}$ & $\begin{array}{l}\text { if } 401<6 \\
0 \rightarrow 418 \\
99 \rightarrow 418\end{array}$ \\
\hline 417 & $\begin{array}{l}\text { In the first three days after delivery } \\
\text { or when you returned to work in the } \\
\text { rice field, was (name) given } \\
\text { anything to drink other than breast } \\
\text { milk? }\end{array}$ & $\begin{array}{l}1 \ldots . . . \text { Yes } \\
0 \ldots \ldots \text {.... } \\
99 \ldots . . \text { Do not know }\end{array}$ & $\begin{array}{l}\text { if } 401<6 \\
\& 407=1\end{array}$ \\
\hline
\end{tabular}


medRxiv preprint doi: https://doi.org/10.1101/2021.07.27.21261221; this version posted July 30, 2021. The copyright holder for this preprint (which was not certified by peer review) is the author/funder, who has granted medRxiv a license to display the preprint in perpetuity.

It is made available under a CC-BY-ND 4.0 International license .

\begin{tabular}{|c|c|c|c|}
\hline \multicolumn{4}{|c|}{$\begin{array}{l}\text { Now, I understand eating pattern of you and your child. I would now like to ask more } \\
\text { about eating practices of women who are breastfeeding. }\end{array}$} \\
\hline 418 & $\begin{array}{l}\text { Yesterday during the day or night, } \\
\text { did you eat more or less or same } \\
\text { amount of food compared to your } \\
\text { eating before this pregnancy? } \\
\text { Probe: Comparing with her usual } \\
\text { eating style. }\end{array}$ & $\begin{array}{l}\text { 1...... Increased amount } \\
2 \ldots . . \text {. Same amount } \\
3 \ldots . . \text {. Decreased amount } \\
99 . . . \text {.Do not know }\end{array}$ & $\begin{array}{l}\text { if } 401<6 \\
\& 407=1\end{array}$ \\
\hline 419 & $\begin{array}{l}\text { Yesterday during the day or night, } \\
\text { did you eat more or less amount of } \\
\text { animal source foods compared to } \\
\text { your eating before this pregnancy? } \\
\text { Probe: Using example of animal } \\
\text { food or product in their general } \\
\text { contexts and comparing with her } \\
\text { usual eating style. }\end{array}$ & $\begin{array}{l}1 \ldots . . \text { Increased amount } \\
2 \ldots . . \text { Same amount } \\
3 \ldots . . \text {. Decreased amount } \\
99 . . . \text {.Do not know }\end{array}$ & $\begin{array}{l}\text { if } 401<6 \\
\& 407=1\end{array}$ \\
\hline
\end{tabular}

\section{Household Food Security and Expenditures}

\section{No. Question $\quad$ Response}

I would like to ask you some questions about how much your household spends on health services and other things.

For all questions in this section report all values in local currency, whether paid in cash or in kind

\begin{tabular}{|l|l|l|}
\hline $\mathbf{5 0 1}$ & $\begin{array}{l}\text { In the last 4 weeks, how much did your household spend } \\
\text { on: }\end{array}$ & $\begin{array}{l}\text { kip } \\
\begin{array}{l}\text { Food, including such things as [rice], meat, fruits, } \\
\text { vegetables, and cooking oils. Include the value of any } \\
\text { food that was produced and consumed by the household, } \\
\text { and exclude alcohol, tobacco and restaurant meals. } \\
\text { In the last 4 weeks, how much did your household spend } \\
\text { on: } \\
\text { Housing, gas, electricity, water, telephone, and heating } \\
\text { fuel }\end{array}\end{array}$ \\
\hline $\mathbf{5 0 3}$ & $\begin{array}{l}\text { In the last 4 weeks, how much did your household spend } \\
\text { on: } \\
\text { Education fees and supplies }\end{array}$ & $\overline{\text { kip }}, 000$ \\
\hline $\mathbf{5 0 4}$ & $\begin{array}{l}\text { In the last 4 weeks, how much did your household spend } \\
\text { on: } \\
\text { Health care costs }\end{array}$ & $\overline{\text { kip }}$ \\
\hline
\end{tabular}


medRxiv preprint doi: https://doi.org/10.1101/2021.07.27.21261221; this version posted July 30, 2021. The copyright holder for this preprint (which was not certified by peer review) is the author/funder, who has granted medRxiv a license to display the preprint in perpetuity.

\begin{tabular}{|c|c|c|c|c|c|}
\hline 505 & \multicolumn{4}{|c|}{$\begin{array}{l}\text { In the last } 4 \text { weeks, how much did your household spend } \\
\text { on: } \\
\text { All other goods and services not yet mentioned }\end{array}$} & ip \\
\hline 506 & \multicolumn{4}{|c|}{$\begin{array}{l}\text { In the last } 4 \text { weeks, how much did your household spend } \\
\text { in total? } \\
\text { (Should equal } 501+502+503+504+505 \text { ) }\end{array}$} & kip \\
\hline 507 & \multicolumn{5}{|c|}{$\begin{array}{l}\text { In the past month, how often have you used any of the methods when you did not } \\
\text { have enough food or money to buy food? }\end{array}$} \\
\hline $507 a$ & \multicolumn{2}{|c|}{$\begin{array}{l}\text { Rely on less preferred, less expensive } \\
\text { foods? }\end{array}$} & \multicolumn{3}{|c|}{$\begin{array}{l}1 \ldots \ldots .1 \text { day per week } \\
2 \ldots \ldots .1-2 \text { days a week } \\
3 \ldots \ldots .3-4 \text { days a week } \\
4 \ldots \ldots .5-6 \text { days a week } \\
5 \ldots . . . \text { Daily } \\
6 \ldots . . . \text { Never } /<1 \text { time per week }\end{array}$} \\
\hline $507 b$ & \multicolumn{2}{|c|}{$\begin{array}{l}\text { Borrow food or money from friends or } \\
\text { relatives? }\end{array}$} & \multicolumn{3}{|c|}{$\begin{array}{l}1 \ldots \ldots .1 \text { day per week } \\
2 \ldots \ldots .1-2 \text { days a week } \\
3 \ldots \ldots . .3-4 \text { days a week } \\
4 \ldots \ldots .5-6 \text { days a week } \\
5 \ldots \ldots . \text { Daily } \\
6 \ldots \ldots . \text { Never } /<1 \text { time per week }\end{array}$} \\
\hline 507c & \multicolumn{2}{|c|}{ Limit portions at mealtimes? } & \multicolumn{3}{|c|}{$\begin{array}{l}1 \ldots \ldots .1 \text { day per week } \\
2 \ldots \ldots .1-2 \text { days a week } \\
3 \ldots \ldots .4-4 \text { days a week } \\
4 \ldots \ldots .6 \text { days a week } \\
5 \ldots \ldots . \text { Daily } \\
6 \ldots \ldots . \text { Never } /<1 \text { time per week }\end{array}$} \\
\hline $507 d$ & \multicolumn{2}{|l|}{ Limit adult intake? } & \multicolumn{3}{|c|}{$\begin{array}{l}1 \ldots \ldots .1 \text { day per week } \\
2 \ldots \ldots .1-2 \text { days a week } \\
3 \ldots \ldots .4 \text { days a week } \\
4 \ldots \ldots .6 \text { days a week } \\
5 \ldots \ldots . . \text { Daily } \\
6 \ldots \ldots . \text { Never } /<1 \text { time per week }\end{array}$} \\
\hline $507 e$ & \multicolumn{2}{|c|}{ Reduce number of meals per day? } & \multicolumn{3}{|c|}{$\begin{array}{l}1 \ldots \ldots .1 \text { day per week } \\
2 \ldots \ldots .1-2 \text { days a week } \\
3 \ldots \ldots . .3-4 \text { days a week } \\
4 \ldots \ldots .6 \text { days a week } \\
5 \ldots \ldots . \text { Daily } \\
6 \ldots \ldots . \text { Never } /<1 \text { time per week }\end{array}$} \\
\hline \multicolumn{6}{|c|}{$\begin{array}{l}\text { Now I would like to ask you some questions about food that the household ate in the } \\
\text { last } 7 \text { days }\end{array}$} \\
\hline & & \multicolumn{2}{|c|}{$\begin{array}{l}\text { 508. How many } \\
\text { days in the past } \\
\text { week (last } 7 \text { days) } \\
\text { did your household }\end{array}$} & \multicolumn{2}{|c|}{$\begin{array}{l}509 \text { What is the source of this } \\
\text { food for each item } \\
\text { mentioned? }\end{array}$} \\
\hline
\end{tabular}


medRxiv preprint doi: https://doi.org/10.1101/2021.07.27.21261221; this version posted July 30, 2021. The copyright holder for this preprint (which was not certified by peer review) is the author/funder, who has granted medRxiv a license to display the preprint in perpetuity.

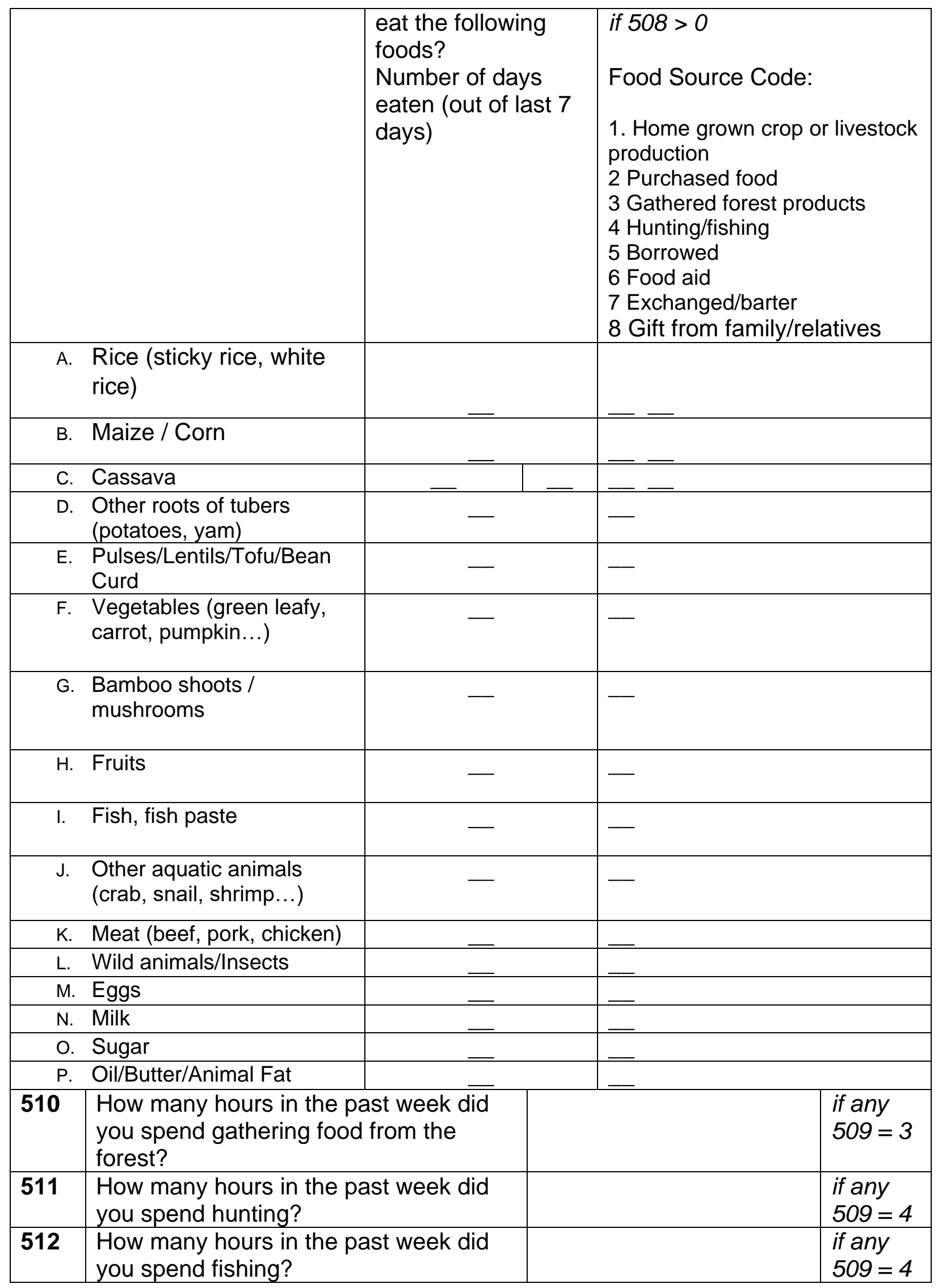


medRxiv preprint doi: https://doi.org/10.1101/2021.07.27.21261221; this version posted July 30, 2021. The copyright holder for this preprint (which was not certified by peer review) is the author/funder, who has granted medRxiv a license to display the preprint in perpetuity.

It is made available under a CC-BY-ND 4.0 International license .

\begin{tabular}{|c|c|c|c|}
\hline 513 & $\begin{array}{l}\text { Compared to before the pandemic, is it } \\
\text { easier or harder to meet your family's food } \\
\text { needs? }\end{array}$ & $\begin{array}{l}\text { 1. Much easier } \\
\text { 2. Somewhat easier } \\
\text { 3. No change } \\
\text { 4. Somewhat harder } \\
\text { 5. Much harder } \\
\text { 99. Don't know/no answer }\end{array}$ & $\begin{array}{l}1 \rightarrow 514 \\
2 \rightarrow 514 \\
3 \rightarrow 514 \\
99 \rightarrow 514\end{array}$ \\
\hline $513 a$ & $\begin{array}{l}\text { What is the reason it is harder to meet your } \\
\text { food needs during the pandemic? } \\
\text { Select all that apply }\end{array}$ & $\begin{array}{l}\text { 1. Items are more } \\
\text { expensive } \\
\text { 2. Markets being closed } \\
\text { 3. Foods not available } \\
\text { 4. HH had lost income. } \\
\text { 98. Others (specify) } \\
\text { 99. Don't know/no answer }\end{array}$ & $\begin{array}{l}\text { if } 513= \\
4 \text { or } 5\end{array}$ \\
\hline 514 & Did you lose income due to the pandemic? & $\begin{array}{l}\text { 1. Yes } \\
0 . \text { No } \\
\text { 99. Don't know/no answer }\end{array}$ & $\begin{array}{l}0 \rightarrow 515 \\
99 \rightarrow 515\end{array}$ \\
\hline $514 a$ & $\begin{array}{l}\text { If yes, how much did you lose, as a } \\
\text { proportion of your income? } \\
\text { (give best guess) }\end{array}$ & $\begin{array}{ll}\text { 1. } & 0-25 \% \\
\text { 2. } & 25-50 \% \\
\text { 3. } & 50-75 \% \\
\text { 4. } & 75-100 \%\end{array}$ & if $514=1$ \\
\hline 515 & $\begin{array}{l}\text { Do you spend less money due to the } \\
\text { pandemic? }\end{array}$ & $\begin{array}{l}\text { 1. Yes } \\
\text { 0. No } \\
\text { 99. Don't know/no answer }\end{array}$ & $\begin{array}{l}0 \rightarrow 516 \\
99 \rightarrow 516\end{array}$ \\
\hline $515 a$ & $\begin{array}{l}\text { If yes, how much did you spend less, as a } \\
\text { proportion of your expenditure? } \\
\text { (give best guess) }\end{array}$ & $\begin{array}{ll}\text { 1. } & 0-25 \% \\
\text { 2. } & 25-50 \% \\
\text { 3. } & 50-75 \% \\
\text { 4. } & 75-100 \%\end{array}$ & if $515=1$ \\
\hline 516 & $\begin{array}{l}\text { Is it more difficult to access health services } \\
\text { now compared to before the pandemic? }\end{array}$ & $\begin{array}{l}\text { 1. Much easier } \\
\text { 2. Somewhat easier } \\
\text { 3. No change } \\
\text { 4. Somewhat harder } \\
\text { 5. Much harder }\end{array}$ & \\
\hline
\end{tabular}

\section{IIIness and Treatment}

Now we would like to ask about any recent illnesses that the selected child (CHILD'S NAME) may have had.

\begin{tabular}{|l|l|l|l|}
\hline No. & Question & Response & \\
\hline $\mathbf{6 0 1}$ & $\begin{array}{l}\text { Did (CHILD'S NAME) have diarrhea in } \\
\text { the past two weeks, where diarrhea is } \\
\text { defined as three or more loose stools or } \\
\text { one loose, bloody stool in a 24 hour } \\
\text { period? }\end{array}$ & $\begin{array}{l}1 \ldots \ldots . . . \text { Yes } \\
0 \ldots . . . \text { No }\end{array}$ & $0 \rightarrow 603$ \\
$99 . \ldots$. Do not know & & \\
\hline
\end{tabular}


medRxiv preprint doi: https://doi.org/10.1101/2021.07.27.21261221; this version posted July 30, 2021. The copyright holder for this preprint (which was not certified by peer review) is the author/funder, who has granted medRxiv a license to display the preprint in perpetuity.

It is made available under a CC-BY-ND 4.0 International license .

\begin{tabular}{|c|c|c|c|}
\hline $602 a$ & $\begin{array}{l}\text { Now I would like to know how much } \\
\text { (CHILD'S NAME) was given to drink, } \\
\text { including breast milk, during the diarrhea } \\
\text { Was he/she given less than usual to } \\
\text { drink, about the same amount, or more } \\
\text { than usual to drink? } \\
\text { If less, probe: Was he/she given much } \\
\text { less than usual to drink or somewhat } \\
\text { less? }\end{array}$ & $\begin{array}{l}\text { 1.......Much less } \\
2 \ldots . . . \text { Somewhat } \\
\text { less } \\
3 \ldots . . . \text { About the } \\
\text { same } \\
4 \ldots . . . \text { More } \\
5 \ldots . . . \text {.Nothing to } \\
\text { drink } \\
99 . . . . \text {. Do not know }\end{array}$ & if $601=1$ \\
\hline $602 b$ & $\begin{array}{l}\text { During the time (CHILD'SNAME) had } \\
\text { diarrhea, was HE/SHE given either: } \\
\text { a) A fluid made from a special packet } \\
\text { called (ORALYTE/NAM THA LAY } \\
\text { PHOUN)? } \\
\text { b) Recommended homemade fluid such } \\
\text { as coconut water or rice water with } \\
\text { salt? }\end{array}$ & $\begin{array}{l}\text { 1.......Yes, Nam Tha } \\
\text { Lay Phoun } \\
2 \ldots \ldots . . \text { Yes, } \\
\text { Recommended } \\
\text { Homemade Fluid } \\
\text { 3........No } \\
99 . . . . \text {... no not know }\end{array}$ & if $601=1$ \\
\hline 602c & $\begin{array}{l}\text { When (CHILD'S NAME) had diarrhea, } \\
\text { was he/she given less than usual to eat, } \\
\text { about the same amount, or more than } \\
\text { usual to eat? } \\
\text { If less, probe: Was he/she given much } \\
\text { less than usual to eat or somewhat less? }\end{array}$ & 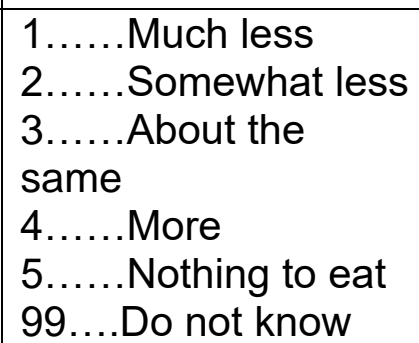 & if $601=1$ \\
\hline 603 & $\begin{array}{l}\text { Has (CHILD'S NAME) been ill with a } \\
\text { fever any time in the past two weeks? }\end{array}$ & $\begin{array}{l}1 \ldots . . \text { Yes } \\
0 \ldots \ldots \text {.... } \\
99 . \ldots . \text {.Do not know }\end{array}$ & \\
\hline 604 & $\begin{array}{l}\text { Has (CHILD'S NAME) had an illness with } \\
\text { a cough at any time in the last two } \\
\text { weeks? }\end{array}$ & $\begin{array}{l}1 \ldots . . . \text { Yes } \\
0 \ldots \ldots \text {.... } \\
99 \ldots . . \text { Do not know }\end{array}$ & $\begin{array}{l}0 \rightarrow 605 \\
99 \rightarrow 605\end{array}$ \\
\hline $604 a$ & $\begin{array}{l}\text { When (CHILD'S NAME) was sick with a } \\
\text { cough, did he/she breathe faster than } \\
\text { normal with short, rapid breaths or have } \\
\text { difficulty breathing? }\end{array}$ & $\begin{array}{l}1 \ldots . . . \text { Yes } \\
0 \ldots \ldots \text {.... } \\
99 \ldots . . \text { Do not know }\end{array}$ & $\begin{array}{l}\text { if } 604=1 \\
0 \rightarrow 605 \\
99 \rightarrow 605\end{array}$ \\
\hline $604 b$ & $\begin{array}{l}\text { Was the fast or difficult breathing due to } \\
\text { a problem in the chest or to a blocked or } \\
\text { runny nose? }\end{array}$ & $\begin{array}{l}\text { 1......Chest only } \\
2 \ldots \ldots \text {.... ose only } \\
3 \ldots \ldots \text { Both } \\
99 \ldots \ldots \text {.... no not know }\end{array}$ & if $604 a=$ \\
\hline 605 & $\begin{array}{l}\text { At any time during the past two weeks, } \\
\text { did you (mother) have diarrhea? }\end{array}$ & $\begin{array}{l}1 \ldots \ldots \text { Yes } \\
0 \ldots \ldots \text {..... } \\
99 \ldots \text {....Do not know }\end{array}$ & \\
\hline 606 & $\begin{array}{l}\text { At any time during the past two weeks, } \\
\text { have you (mother) been ill with a fever? }\end{array}$ & $\begin{array}{l}1 \ldots \ldots . \text { Yes } \\
0 \ldots \ldots \text {.... No }\end{array}$ & \\
\hline
\end{tabular}




\begin{tabular}{|c|c|c|c|}
\hline & & 99......Do not know & \\
\hline 607 & $\begin{array}{l}\text { When (CHILD'S NAME) was sick, did } \\
\text { you seek advice or treatment from any } \\
\text { source? }\end{array}$ & $\begin{array}{l}1 \ldots . . \text { Yes } \\
0 \ldots \ldots \text {.... } \\
99 \ldots . . \text { Do not know }\end{array}$ & $\begin{array}{l}\text { if } 601 \text {, } \\
603 \text { or } \\
604=1 \\
0 \rightarrow 609 \\
99 \rightarrow 609\end{array}$ \\
\hline 608 & $\begin{array}{l}\text { From where did you seek advice or } \\
\text { treatment? } \\
\text { Probe: Anywhere else? } \\
\text { (Multiple response) }\end{array}$ & 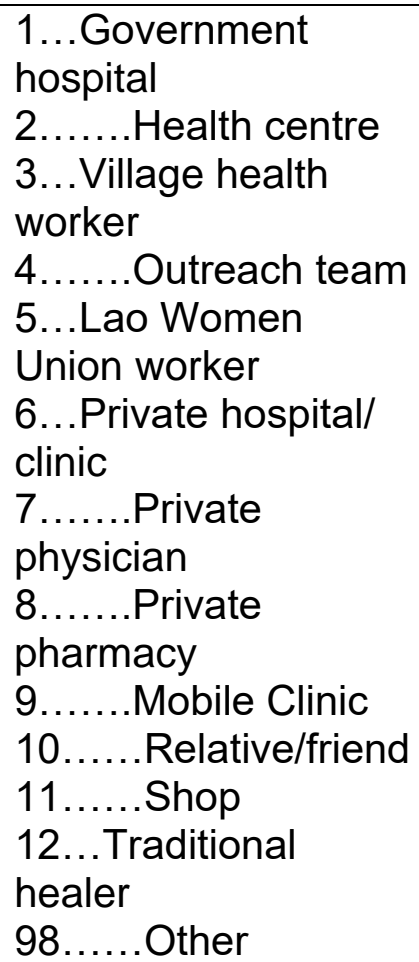 & if $607=1$ \\
\hline 609 & $\begin{array}{l}\text { When (YOU) was sick, did you seek } \\
\text { advice or treatment from any source? }\end{array}$ & $\begin{array}{l}1 \ldots . . . \text { Yes } \\
0 \ldots . . . \text { No } \\
99 . . . . \text {.Do not know }\end{array}$ & $\begin{array}{l}\text { if } 605 \text { or } \\
606=1 \\
0 \rightarrow 700 \\
99 \rightarrow 700\end{array}$ \\
\hline 610 & $\begin{array}{l}\text { From where did you seek advice or } \\
\text { treatment? } \\
\text { Probe: Anywhere else? } \\
\text { (Multiple response) }\end{array}$ & 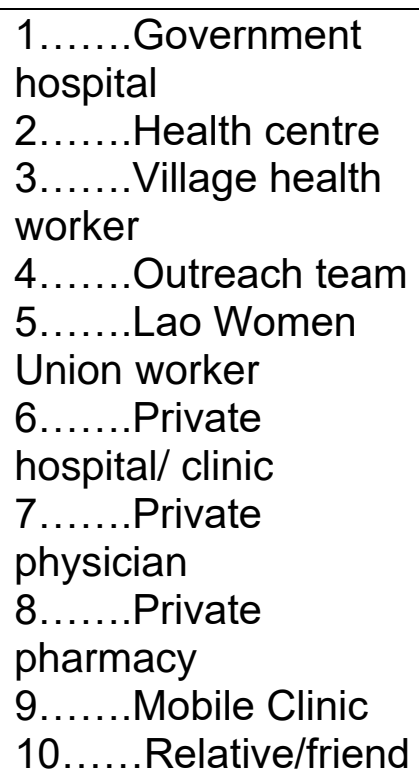 & if $609=1$ \\
\hline
\end{tabular}


medRxiv preprint doi: https://doi.org/10.1101/2021.07.27.21261221; this version posted July 30, 2021. The copyright holder for this preprint (which was not certified by peer review) is the author/funder, who has granted medRxiv a license to display the preprint in perpetuity.

\begin{tabular}{|l|l|l|}
\hline & $11 \ldots \ldots$ Shop & \\
& $12 \ldots$ Traditional & \\
& healer & \\
& $98 \ldots \ldots$ Other & \\
\hline
\end{tabular}

\section{Anthropometry}

\begin{tabular}{|l|l|l|l}
\hline No & Question & Response & Notes
\end{tabular}

As part of this survey, we are measuring the growth of children 0-59 mo. Child growth is an important indicator of health. Poor growth is a serious health problem that usually results from poor nutrition, poor sanitation, or infection. This measurement will help us design programs to improve child health. We will share with you the measurements, but will not share the information with anyone else outside the survey team. Do you have any questions?

\begin{tabular}{|c|c|c|c|}
\hline 901 & What is the age, in months, of (NAME)? & & $\begin{array}{l}\text { Same as } \\
401\end{array}$ \\
\hline 902 & What is the sex of (NAME)? & $\begin{array}{l}0 \ldots . . . . \text { Female } \\
\text { 1.......Male }\end{array}$ & \\
\hline 903 & $\begin{array}{l}\text { Enumerator: Check for bilaterial pitting } \\
\text { edema }\end{array}$ & $\begin{array}{l}\text { 1......Present } \\
0 \ldots . . . \text { Not present } \\
99 \ldots . \text { Unsure } \\
\text { 98....Not checked }\end{array}$ & $1 \rightarrow 906$ \\
\hline 904 & $\begin{array}{l}\text { Now I am going to weigh (NAME). } \\
\text { Enumerator: If the child is under } 2 \text { years } \\
\text { old, weigh the mom by herself. The child } \\
\text { should wear as few clothes as possible. If } \\
\text { the child is wearing clothes, weigh the mom } \\
\text { holding an extra pair of clothes (if an } \\
\text { extra pair exists) similar to the weight of the } \\
\text { clothes the child is wearing. Tare the } \\
\text { scale. Then weigh the mom holding the child. } \\
\text { Record the weight of the child. }\end{array}$ & $\mathrm{kg}$ & if $903=0$ \\
\hline 905 & $\begin{array}{l}\text { Enumerator: was (NAME) undressed to the } \\
\text { minimum? } \\
\text { (note...if child was dressed but mother held } \\
\text { clothes, indicate 'no clothes') }\end{array}$ & $\begin{array}{l}0 \ldots . . . \text { No clothes } \\
1 \ldots \ldots . \text {....ew clothes } \\
2 \ldots \ldots . \text { Many } \\
\text { clothes }\end{array}$ & \\
\hline 906 & $\begin{array}{l}\text { Now I am going to measure the arm of } \\
\text { (NAME). } \\
\text { Enumerator: record the MUAC } \\
\text { measurement, in } \mathrm{cm}\end{array}$ & $\mathrm{cm}$ & if $401 \geq 6$ \\
\hline 907 & Record the color of the MUAC tape & $\begin{array}{l}1 \ldots . . . \text { Green } \\
2 \ldots . . \text { Yellow } \\
3 \ldots \ldots \text {....ed }\end{array}$ & if $401 \geq 6$ \\
\hline
\end{tabular}




\begin{tabular}{|c|c|c|}
\hline 908 & $\begin{array}{l}\text { Now I am going to measure the height of } \\
\text { (NAME). } \\
\text { Enumerator: record the height } \\
\text { measurement of the child, in cm. If the child } \\
\text { is less than } 23 \text { months, measure the child } \\
\text { lying down. }\end{array}$ & $\mathrm{cm}$ \\
\hline 909 & $\begin{array}{l}\text { How was the person actually measured? } \\
\text { Lying down or standing up? }\end{array}$ & $\begin{array}{l}\text { 1.......Lying down } \\
2 \ldots . . . \text { Standing }\end{array}$ \\
\hline 910 & $\begin{array}{l}\text { Now I am going to measure your arm. } \\
\text { Enumerator: record the MUAC } \\
\text { measurement of the mother, in } \mathrm{cm} \text {. }\end{array}$ & $\overline{\mathrm{cm}}$ \\
\hline
\end{tabular}

\section{Closing Statement to the Interview}

The interview is complete. Thank you so much for your time and patience. Your help will allow us to work together to improve the health and nutrition of your child and community.

Enumerators: indicating completeness:

$\square$ Yes, interview is complete $\Rightarrow$ Move to the next household No, interview was not complete $\Rightarrow$ Tell this result to your supervisor and move to the next household. 